\title{
Los derechos sucesorios del viudo en Vizcaya y Ayala (I) El usufructo legal del viudo en Vizcaya: naturaleza jurídica, requisitos y objeto ${ }^{1}$
}

\author{
Manuel Calduch Gargallo \\ Licenciado en Derecho por la Universidad de Valencia \\ DEA en Derecho Civil por la Universidad de Zaragoza
}

Recibido: 03.07 .06

Aceptado: 10.10 .06

\begin{abstract}
Resumen: Dentro de la pluralidad de legislaciones civiles que conviven en España, el modelo vasco se convierte en paradigma de la idea, defendida doctrinalmente, de que en aquellos sistemas en los que el régimen económico matrimonial es el de separación de bienes, suelen concederse amplios derechos sucesorios al viudo, mientras que, en aquellos que parten de un sistema de comunidad, los derechos mortis causa que se le conceden o no existen, o son mínimos, puesto que la protección a su posible situación de desvalimiento se obtiene ya a través del régimen económico matrimonial. Este es el caso del País Vasco, donde rige un sistema legal de comunidad como es el de comunicación foral de bienes. La existencia de este régimen económico matrimonial legal, que concede a los cónyuges medios suficientes para dirigir a la familia en caso de disolución -sobre todo si ésta es debida al fallecimiento de uno de sus miembros y existe descendencia- justifica que los derechos usufructuarios del viudo no tengan por qué ser del alcance de los existentes en Navarra o en Aragón, para permitir una protección suficiente del supérstite. Pues bien, el presente trabajo pretende examinar con cierta profundidad la naturaleza jurídica del usufructo legal previsto en la legislación foral del País Vasco, sus requisitos, objeto y extinción. Asimismo se examinan otros derechos usufructuarios viduales previstos en esa norma, como el usufructo universal derivado del poder testatorio, el usufructo poderoso del Fuero de Ayala y el legado del usufructo universal.
\end{abstract}

Palabras clave: Usufructo legal. Cónyuge viudo. Derecho foral. Fuero de Ayala.

Abstract: Inside the wide range of Civil Laws which live together in Spain, the Basque regulations are the model for those authors who think that the Marriage Economic Systems of separating goods use to be accompanied by wide inheritance rights for the widow, whereas in those Marriage Economic Systems with community goods, the mortis causa rights do not exist, or they are fewer because the protection against their hypothetical needy situation can be obtained through the community goods system. This is the Basque Country case where a Legal Marriage Economic System of common goods, known as «comunicación foral de bienes», is ruled. The existence of this system which gives the spouses enough tools for ruling the family in case of marriage dissolution-above all if this is caused by the death of one of its partners and there are offspring-justifies that widow rights of use and enjoyment do not require to be so extensive that Navarri-

${ }^{1}$ A mi madre, que está en el cielo. 
an's or Aragonian's, in order to achieve an adequate protection to the widow. Therefore this research tries to analyse with intensity, the right content of the legal use and enjoyment established in the Basque Country Law, its requirements, the enjoyable goods and its extinction. Furthermore other widow rights of use and enjoyment written in the Law are analysed, like the Full Enjoyment that the Power of Will (the so-called "poder testatorio») provides with, the powerful right of use and enjoyment of the Ayala Law (the so-called «usufructo poderoso del Fuero de Ayala») and the legacy of the Full Enjoyment.

Key words: Widow benefit. Surviving spouse. Civil Law of the Basque Country.

Sumario: I. Introducción.-II. El usufructo legal del viudo en Vizcaya. A. Su naturaleza jurídica. B. Requisitos del usufructo vidual legal. 1. La subsistencia del matrimonio o de la pareja de hecho. 2. La no separación. 3. No tener un hijo fuera del matrimonio, o de la relación de pareja, durante su vigencia. 4. No incurrir en causas de indignidad para suceder. a) El abandono, prostitución o corrupción de los hijos. b) La condena en juicio por atentar contra la vida del cónyuge, compañero de la pareja de hecho, descendientes o ascendientes. c) La condena por acusación calumniosa contra el premuerto. d) La ausencia de denuncia a la justicia de la muerte violenta del cónyuge o pareja. e) La coacción al cónyuge, o compañero, para que otorgue testamento o lo modifique. f) La coacción al testador para impedirle testar, forzarle a revocar el testamento o su suplantación, ocultación o alteración. g) La no prestación de atenciones debidas al cónyuge o compañero discapacitado. C. El objeto del usufructo vidual legal.--III. Conclusiones.--IV. Bibliografía.

\section{Introducción}

Dentro de los ordenamientos civiles que conviven en España, podemos identificar dos regulaciones que, en el ámbito de los usufructos legales en favor del viudo, se manifiestan como paradigmas de modelos diferentes. Me estoy refiriendo a la legislación navarra y a la catalana. Cada una de ellos representa el extremo opuesto en una supuesta graduación de mayor o menor amplitud de los derechos del cónyuge supérstite.

En el caso navarro, se parte de un régimen económico matrimonial legal de comunidad - la denominada sociedad conyugal de conquistas- caracterizado básicamente porque los bienes ganados durante el matrimonio se hacen comunes. En consecuencia, en el momento de su disolución y liquidación, cada cónyuge o sus herederos recibirán, salvo pacto en contrario, la mitad de ellos. Pero, al margen de esta protección, el Derecho foral navarro concede al viudo una protección adicional que, además, entra en funcionamiento con independencia del régimen económico matrimonial que rija a los consortes: se trata del usufructo de fidelidad. En virtud de ello, como regla general, el 
viudo adquirirá a la muerte de su cónyuge el usufructo de todos los bienes de la herencia. Nos encontramos, por tanto, ante un ordenamiento que configura legalmente un régimen económico matrimonial de comunidad y que atribuye al supérstite importantísimos derechos sucesorios consistentes en el usufructo sobre el conjunto del patrimonio hereditario.

Frente al sistema navarro, el ordenamiento jurídico catalán parte de un régimen económico matrimonial de separación en el que los cónyuges conservan su patrimonio individualizado. Y pese a ello, los derechos sucesorios que se conceden por Ley al viudo no alcanzan la amplitud navarra. Así, se prevé un usufructo vidual intestado que, como su propio nombre indica, únicamente procede cuando la sucesión abierta es intestada y que, además, no puede alcanzar a las legítimas ni a las donaciones por causa de muerte o a los legados hechos en codicilo a favor de otras personas. También se regula la denominada quarta vidual, que garantiza que el supérstite mantendrá un nivel de vida congruente con su posición anterior al fallecimiento de su consorte, lo que le permite asegurar que su patrimonio tras esa muerte no quede por debajo de la cuarta parte de la herencia líquida del premuerto. Asimismo, se recogen otras medidas protectoras de menor entidad como l'any de viduïtat, o se permite el pacto o la concesión de usufructos universales en favor del consorte, si bien esta última posibilidad juega al margen del sistema configurado legalmente. Nos encontramos, por tanto, en el sistema catalán, ante un régimen económico matrimonial de separación de bienes que no va acompañado de la concesión de amplios derechos sucesorios para el viudo.

Ambos ordenamientos jurídicos -el catalán y el navarro- son un claro ejemplo de trasgresión de la idea, defendida doctrinalmente, de que, en aquellos sistemas en los que el régimen económico matrimonial es el de separación de bienes, suelen concederse amplios derechos sucesorios al viudo, mientras que, en aquellos que parten de un sistema de comunidad, los derechos mortis causa que se le conceden o no existen, o son mínimos, puesto que la protección a su posible situación de desvalimiento se obtiene ya a través del régimen económico matrimonial ${ }^{2}$.

En medio de ambos modelos, encontramos el ejemplo vizcaíno. En él sí que podemos observar una estrecha relación entre los derechos hereditarios del viudo y el régimen económico matrimonial legal de comunicación foral de bienes que rige en Vizcaya ${ }^{3}$. En virtud de este régimen de comunicación,

\footnotetext{
${ }^{2}$ Vid. en este sentido Zabalo Escudero, M. E., La situación jurídica del cónyuge viudo en el Derecho internacional privado e interregional, Ed. Aranzadi, Pamplona, 1993, y la bibliografía por ella citada en pp. 15-ss., entre otras. Vid, también VALLET DE GoYTISOLO, J., «Comentarios a la sección séptima», en Comentarios al Código civil y Compilaciones forales, dirigidos por M. Albaladejo, T. XI, 2a Ed. (Edersa, Madrid 1.982,), pág. 442.

${ }^{3}$ Vid. Celaya IbarRa, A., «Comentarios al artículo 58 de la Ley del Derecho civil foral del País Vasco», en Comentarios al Código civil y Compilaciones forales, dirigidos por M. Albaladejo y Silvia Díaz Alabart, t. XXVI, Edersa, Madrid, 1997, p. 247.
} 
se hacen comunes por mitad, entre marido y mujer, todos los bienes muebles o raíces, de la procedencia que sean, pertenecientes a ambos cónyuges por cualquier título, tanto los aportados como los adquiridos durante el matrimonio y sea cual fuere el lugar en que radiquen. Se parte, por tanto, de un régimen de comunidad universal. En éste se plantea la distinción entre los bienes ganados y aquellos procedentes de cada uno de los cónyuges, pero dicha distinción se hace fundamentalmente a fin de determinar la limitación de la responsabilidad de los segundos en los casos de deudas y obligaciones contraídas sin el consentimiento del otro consorte, y también al objeto de aclarar que su administración corresponde al cónyuge del que proceden. Pero, en cuanto a la disposición, se requerirá siempre el consentimiento de ambos consortes ${ }^{4}$.

El régimen de comunicación de bienes de Vizcaya se disuelve por acuerdo de las partes y también en virtud de sentencia de nulidad del matrimonio, de divorcio o de separación. Pero, el supuesto que aquí nos interesa -por su estrecha relación con los derechos usufructuarios del viudo- es el de su extinción como consecuencia de la muerte de uno de los cónyuges. Producido ese fallecimiento, la Ley 3/1992, de 1 de julio, de Derecho civil foral del País Vasco, distingue según el matrimonio haya dejado, o no, hijos o descendientes comunes.

En el caso de que no hubiera tal descendencia, la comunicación cesa y los bienes se reparten como en una sociedad de gananciales ${ }^{5}$ : básicamente, los bienes ganados se distribuirán por mitad y aquellos que sean de la procedencia de cada cónyuge -o que se hubieren adquirido con ellos o con su importe- se le atribuirán a él.

Y si hubiera descendencia, se consolida la comunicación foral ${ }^{6}$. Lo que se quiere decir con esta expresión es que los bienes y derechos que los cónyuges poseían en el momento de la disolución del matrimonio por muerte son los que, exclusivamente, pasan a formar parte de la comunidad que se forma entre el supérstite y los hijos y descendientes comunes. Con anterioridad a la Ley 3/1992, la Compilación decía que la comunicación «continuaba» entre el viudo y los sucesores, lo que podía llevar a pensar que el mismo sistema que funcionaba en vida de ambos consortes debía seguir haciéndolo tras el fallecimiento de uno de ellos, entre el sobreviviente y los hijos y des-

\footnotetext{
${ }^{4}$ Vid. Piedrabuena Molina, P., «La comunicación foral de bienes en Vizcaya» en Derechos Civiles de España, VV.AA., Volumen I, Ed. Aranzadi. 2.000, pp. 347-ss.

${ }^{5}$ Vid. Celaya IBarRa, A., «Comentarios al artículo 104 de la Ley del Derecho civil foral del País Vasco», en Comentarios al Código civil y Compilaciones forales, dirigidos por M. Albaladejo y Silvia Díaz Alabart, t. XXVI, Edersa, Madrid, 1997, p. 472.

${ }^{6}$ Dice el artículo 104 de la Ley del Derecho civil foral del País Vasco que «cuando el matrimonio se disuelva por la muerte de uno de los cónyuges, dejando hijos o descendientes comunes, se consolida la comunicación foral y se transforma en comunidad de bienes entre el cónyuge viudo, de una parte, y los hijos o descendientes que sean sucesores del premuerto, de otra, hasta la división y adjudicación de los bienes».
} 
cendientes, de tal forma que tanto los bienes de los padres, como los de los hijos -como también los adquiridos por unos y otros- se hacían comunes, dividiéndose después por cabezas. Para evitar esa interpretación -contraria a lo que había sido el tradicional funcionamiento de la comunicación foral- la nueva Ley sustituyó el término «continuar» por el de «consolidar», dando a entender que la nueva comunidad únicamente afectaba a aquellos bienes y derechos que poseía el matrimonio antes del fallecimiento de uno de los cónyuges. Esa comunidad que se forma permanecerá hasta que se proceda a la división y adjudicación de los bienes. Y, en caso de que se hubiera designado comisario, hasta que se designe sucesor, correspondiendo al cónyuge viudo, salvo disposición contraria del testador, la administración de todo el caudal mientras no sea aceptada la sucesión por aquéllos. Hay que tener en cuenta, además, que son frecuentes los poderes testatorios que acaban otorgando a esta comunidad una duración que suele extenderse hasta la muerte del viudo ${ }^{7}$.

Nos encontramos, por lo tanto, ante un régimen económico matrimonial legal de comunidad. En el caso de que no exista descendencia, el viudo, por medio de su disolución, obtendrá, al menos, la mitad de los bienes ganados por esa comunidad durante el matrimonio y recuperará los bienes de su procedencia. Y si hubiera resultado fecundo, la comunicación se extiende incluso más allá de la muerte de uno de los cónyuges, permitiendo al supérstite -salvo disposición en contrario del testador- representar y administrar el caudal hereditario. La existencia de este régimen económico matrimonial legal, que concede a los cónyuges medios suficientes para dirigir a la familia en caso de disolución -sobre todo si ésta es debida al fallecimiento de uno de sus miembros y existe descendencia- justifica que los derechos usufructuarios del viudo no tengan por qué ser del alcance de los existentes en Navarra o en Aragón, para permitir una protección suficiente del supérstite. De hecho, el artículo 58 de la Ley 3/1992 determina que «el cónyuge viudo tendrá el usufructo de la mitad de todos los bienes del causante, si concurriera con descendientes o ascendientes.// En defecto de ascendientes o descendientes, tendrá el usufructo de dos tercios de todos los bienes». Es decir, que, a diferencia de lo que se prevé para el caso de las dos Comunidades mencionadas, en Vizcaya el usufructo no tiene un alcance universal.

Esta combinación de un régimen económico matrimonial legal de amplia comunidad y unos derechos sucesorios, en cierta manera reducidos, convierten al modelo vasco en un ejemplo de la afirmación doctrinal -a la que antes nos referimos- de que los regímenes económicos matrimoniales de tipo

\footnotetext{
${ }^{7}$ Además, tal y como dispone el último párrafo del artículo 105, salvo que el testador haya dispuesto lo contrario, si el cónyuge viudo es designado comisario único o con otras personas, mientras no haga uso del poder testatorio, tendrá el usufructo del caudal hereditario.
} 
ganancial suelen ir acompañados de limitados derechos sucesorios y, a la inversa, que regímenes de separación de bienes suelen combinarse con amplios derechos mortis causa en favor de los viudos. Sin embargo, hemos de dejar constancia de que la previsión legal del artículo 58, en relación con el usufructo vidual, entra en funcionamiento tanto si nos encontramos ante un matrimonio que se rige por el régimen legal de comunicación foral, como si han pactado un modelo distinto como, por ejemplo, el de separación de bienes; $y$, en el primer caso, tanto si el matrimonio no ha tenido descendencia $-y$, por consiguiente, la disolución de su régimen económico matrimonial funciona como un clásico régimen de gananciales- como si la hubiera tenido -supuesto en el que la comunidad puede extenderse temporalmente y los derechos del supérstite sobre el caudal hereditario pueden ser mucho más extensos-. En definitiva, el abanico de posibilidades en cuanto a la protección del viudo es muy amplio y abarcará desde una altísima protección en el último caso $^{8}$, hasta posibles situaciones en las que el régimen económico matrimonial pactado sea el de separación de bienes y la cobertura del supérstite pueda resultar insuficiente.

Pero para llegar al actual nivel de derechos del supérstite, el ordenamiento vizcaíno ha requerido del paso del tiempo. Su ejemplo es el propio de la evolución histórica de los países desarrollados en lo que se refiere a la consideración del viudo como sujeto jurídico digno de protección. En la primitiva redacción del Fuero de 1526, su figura se encontraba protegida -siempre y cuando hubiera descendencia común con el premuerto- a través del régimen económico matrimonial que permitía que todos los bienes fueran comunes y, en consecuencia, que el supérstite pudiera disfrutar de su mitad en plenitud. Además, era habitual bajo su vigencia el otorgamiento del poder testatorio a su favor, lo que iba a permitirle disfrutar también de la otra mitad. Sin embargo, careciendo de descendencia común y no siendo la casa en la que se habitaba de la familia del supérstite, sólo tenía derecho a recuperar la dote aportada, pudiendo permanecer en esa casa mientras no le fuera devuelta dicha dote. Y, en los demás casos, sólo se le reconocía el derecho a permanecer en ella durante el año siguiente a la muerte de su consorte?

\footnotetext{
${ }^{8}$ Sería el supuesto del denominado alkar poderoso, consistente en la concesión del poder testatorio en favor del viudo con la finalidad de otorgarle una situación privilegiada de manera que no solamente haga suya la mitad de los bienes, cuando haya hijos, sino permitiéndole también que administre y usufructúe la otra mitad destinada a los herederos legítimos. En ocasiones incluso se otorga una prórroga indefinida para el ejercicio de ese poder, facilitando el mantenimiento de esa administración y ese usufructo de por vida. Si así fuera, el usufructo del artículo 58 sería absorbido por el más amplio concedido por el cónyuge. Vid. Celaya Ibarra, A., «Comentarios al artículo 32 de la Ley del Derecho civil foral del País Vasco», en Comentarios al Código civil y Compilaciones forales, dirigidos por M. Albaladejo y Silvia Díaz Alabart, t. XXVI, Edersa, Madrid, 1997, p. 164.

${ }^{9}$ Se trata del año de luto, institución común con otras existentes en los derechos forales y que subsisten en alguno de esos ordenamientos, como l'any de viduïtat en Cataluña. Vid.
} 
En realidad, lo que mostraba esta regulación era una preocupación por la permanencia de «la casa», por su dirección y continuidad. Si cuando había descendencia se le concedía al viudo el disfrute de los bienes del matrimonio a través de su participación en la comunidad -y la correspondiente atribución de aquellos que le correspondían en su disolución- y a través, también, del poder testatorio, era porque se necesitaba de alguien que rigiera los intereses de la familia que el fallecido tenía en común con el viudo. Cuando no existía tal descendencia, sus derechos eran mínimos, puesto que no había nada que continuar, no existía familia que regir ni patrimonio que proteger.

Con el paso de los siglos, tal configuración se mostró inapropiada. El siglo XX abrió un periodo de preocupación real por la situación económica del cónyuge tras el fallecimiento de su pareja. Así, tras los infructuosos intentos de Proyectos de Apéndice de 1900 y 1928, se llegó a la Compilación de 1959 que permitía que el cónyuge viudo tuviera el usufructo de la mitad de los bienes de libre disposición cuando no concurriera con hijos o descendientes legítimos. Habiendo hijos no se le concedía tal derecho, por cuanto se consideraba que ya se encontraba protegido a través del régimen económico-matrimonial de comunicación foral. No obstante, la variabilidad de los bienes de libre disposición, dependiendo de los herederos en concurrencia, podía convertir en mínimo ese usufructo: éste sería el caso si existieran ascendientes puesto que, en tal supuesto, los bienes de libre disposición quedaban limitados a una quinta parte del total de la herencia. Y de ahí, hemos llegado al régimen actual del mencionado artículo 58, que extiende el usufructo de viudedad tanto a los supuestos en los que existan descendientes o ascendientes, como en el que no los haya, y con independencia del régimen económico que rija el matrimonio.

A todo ello habrá que añadir la reciente publicación de la Ley 7/2003, de 7 de mayo, del Parlamento Vasco, reguladora de las Parejas de Hecho. Esta norma dispone en su artículo 9, titulado «Régimen sucesorio», que «a los efectos de la Ley 3/1992, de 1 de julio, de Derecho Civil Foral del País Vasco, las parejas de hecho tendrán la misma consideración que las casadas (...)». A continuación, ese mismo artículo 9, en una relación que parece de numerus apertus, señala una serie de supuestos en los que se produce dicha equiparación, coincidiendo todos ellos en que se trata de admitir la posibilidad de pactos o de disposiciones mortis causa para los miembros de la pareja estable en concordancia con lo que es admitido entre los cónyuges. No se recoge en dicha enumeración ninguna referencia a la aplicación de los preceptos relativos a la sucesión legal. Sin embargo, dado que -como he dichola relación parece abierta, debe entenderse, conforme al enunciado general

Celaya Ibarra, A., «Comentarios al artículo 58 de la Ley del Derecho civil foral del País Vasco», en Comentarios al Código civil y Compilaciones forales, dirigidos por M. Albaladejo y Silvia Díaz Alabart, t. XXvi, Edersa, Madrid, 1997, pp. 247 y 248. 
de que «las parejas de hecho tendrán la misma consideración que las casadas», que la posición del «viudo» de una pareja estable debe ser la misma a efectos sucesorios que la del «viudo tradicional». Por tanto, parece que el derecho de usufructo a que se refiere el artículo 58 también debe corresponder al miembro de la pareja estable -aun cuando fuera del mismo sexo que el causante (art. 2 Ley 2/2003) - que, conforme a lo establecido en el artículo 3 de esta Ley, se hubiera inscrito en el correspondiente Registro de Parejas de Hecho. En definitiva, vemos que esa evolución histórica del derecho de usufructo vidual ha desembocado finalmente en su concesión incluso a personas que no encajan en el concepto tradicional de viudo. Sería de agradecer, no obstante, que, puesto que dicha Ley tiene sus correspondientes consecuencias sobre la Ley del Derecho Civil del País Vasco, se procediera por el legislador a dar nueva redacción a los preceptos afectados a fin de garantizar la seguridad jurídica de sus ciudadanos. Por todo lo dicho, las referencias que en el presente trabajo realizo al cónyuge viudo, en relación al usufructo legal de viudedad, deben entenderse efectuadas, igualmente, al miembro supérstite de la pareja estable.

Por último, quiero dejar constancia de que el presente artículo es parte de una obra de mayor extensión en la que, además de completarse el examen del usufructo legal del viudo con el análisis de sus causas de extinción, se aborda el estudio de otros derechos usufructuarios previstos por la legislación civil del País Vasco, tales como el usufructo universal del poder gestatorio, el usufructo poderoso del Fuero de Ayala y el legado de usufructo universal. El examen de todo ello será objeto de una próxima entrega.

\section{El usufructo legal del viudo en Vizcaya}

\section{A. Su naturaleza jurídica}

El problema de la naturaleza jurídica de los derechos para la protección del viudo concebidos legalmente por los distintos ordenamientos jurídicociviles del Estado español no ha sido resuelto pacíficamente por la doctrina. Así, por ejemplo, en algunos casos, pese a la configuración legal sucesoria del derecho, se ha defendido por algún sector su naturaleza familiar. Recordemos, por ejemplo, el caso de la fidelidad navarra: la Compilación no duda en ubicar su regulación dentro del capítulo dedicado a las limitaciones a la libertad de disponer, en el Libro II relativo a las donaciones y sucesiones; y, sin embargo, se ha defendido, en bastantes ocasiones, su carácter familiar. Y es que en la fidelidad navarra -como en otras figuras de trazos similares en los derechos forales- se combina un deseo de protección patrimonial del viudo con un objetivo de permanencia y de cohesión familiar. El derecho se concede al supérstite no sólo para mejorar o mantener su status, sino también para que pueda ejercer con las adecuadas garantías la auctoritas familiae, velando por los intereses del patrimonio y por la cohesión del grupo. Por 
ello, algunos autores consideran que este segundo aspecto -el que incide en su faceta de permanencia de la unión de la familia, de búsqueda del interés común- era el realmente relevante a la hora de determinar su naturaleza. Y con fundamento en ello, defienden su carácter familiar ${ }^{10}$.

En el caso vizcaíno, sin embargo, no han existido divergencias a la hora de calificar este derecho. Su regulación se recoge, básicamente, en el artículo 58 de la Ley 3/1992, de 1 de julio, del Derecho civil del País Vasco, ubicado dentro del Capítulo II -titulado «De la sucesión forzosa»- del Título III dedicado a las sucesiones. Nadie ha discutido esta naturaleza sucesoria y ello a pesar de que entre las causas que dan lugar a su extinción se recogen algunas comunes a otras instituciones calificadas por ciertos autores como de naturaleza familiar, tales como las nuevas nupcias o la unión marital de hecho. Incluso se añaden otras que inciden en el comportamiento «infiel» del consorte con respecto al premuerto, como el de tener un hijo no matrimonial durante la vigencia de la unión o con posterioridad a ella. Podía haberse defendido que el nuevo matrimonio o la unión marital de hecho, en cuanto suponen el comienzo de una nueva célula familiar, rompen la cohesión o la unión de la que el supérstite formaba con los hijos del fallecido ${ }^{11}$. También la infidelidad, manifestada a través del hijo concebido durante la relación conyugal con el premuerto (a la que deberemos entender equiparada la relación de hecho de la pareja estable inscrita como tal), o con posterioridad a ésta, y siempre fuera de ella, podía haberse visto como un ataque a la esencia familiar, como una manifestación de la poca confianza que merece para regir los destinos del grupo quien no ha sido capaz de mantenerse fiel a la memoria del difunto. Con base en ello, podía haberse incidido en los aspectos familiares de la institución ${ }^{12}$. Y, sin embargo, nadie ha cuestionado su esencia sucesoria. Más bien se ha visto esa finalidad de mantener la cohesión y la unidad familiar durante la vida del supérstite en el específico régimen

${ }^{10}$ Vid., en este sentido, LACRUZ Berdejo, J. L., «Cuestiones fundamentales de viudedad foral navarra» en Revista Crítica de Derecho Inmobiliario, año XL, septiembre-octubre 1964, núm. 436-437, pp. 567-ss. También, entre otros, ARREgui GIL, J. en «Comentarios a la Ley 253» en Comentarios al Código civil y Compilaciones forales, dirigidos por M. Albaladejo y Silvia Díaz Alabart, t. XXXVII, vol. 2. ${ }^{\circ}$, Edersa, Madrid, 2001, p. 37 -aunque matizadamente- defiende esa naturaleza al entender que, por la confluencia de los elementos sucesorios y familiares en el usufructo de fidelidad, «se puede seguir manteniendo que (...) es una institución familiar post mortem, familiar sucesoria». En mi opinión, sin embargo, debe defenderse su naturaleza sucesoria básicamente porque su nacimiento no deriva de la celebración del matrimonio, sino del fallecimiento del consorte. Todo ello sin perjuicio de reconocer determinados caracteres familiares de esa institución.

${ }^{11}$ En realidad, lo que le importa a la Ley es que estos nuevos hechos provocan la desaparición de las circunstancias que podían motivar el desamparo económico del viudo.

${ }^{12}$ Siendo esto cierto, la infidelidad que interesa es la del supérstite con respecto al premuerto, sin que al legislador le preocupen, a estos efectos, los problemas en las relaciones del viudo con otros miembros de la familia. 
económico matrimonial vizcaíno de comunicación: el hecho de que el viudo adquiera la mitad de los bienes de la comunidad y de que se consolide la comunicación con los hijos o descendientes que sean sucesores del premuerto hasta la división y adjudicación de los bienes es lo que va a permitir regir a la familia con la misma autoridad que se ostentaba con anterioridad al fallecimiento del cónyuge ${ }^{13}$. Sobre todo si tenemos en cuenta que el supérstite es, en principio, el único representante y administrador de la herencia, en tanto ésta no sea aceptada; y que, además, si es nombrado comisario, salvo disposición en contrario, tendrá el usufructo sobre toda la herencia.

En nuestra opinión, la naturaleza sucesoria del usufructo en favor del viudo, se fundamenta en que es la muerte del cónyuge -o compañero en la pareja estable- la que determina que el derecho llegue a nacer para el supérstite. Dice el artículo 58 que es «el cónyuge viudo» quien tendrá el usufructo sobre la mitad o los dos tercios de todos los bienes del causante. Es decir, se requiere tener esa condición de viudedad para que el derecho nazca, luego es la muerte del consorte la que origina el usufructo. El derecho no nace con el matrimonio -o con la inscripción de la pareja estable conforme al artículo 3 de la Ley 2/2003-. Éste sólo crea una expectativa de que en un futuro pueda corresponder el disfrute sobre determinados bienes, pero la celebración de las nupcias, o la inscripción de la pareja, no impone un gravamen que siga a los bienes desde ese momento ${ }^{14}$. A ello debemos añadir como argumento -que, aunque no sea decisivo, sí que permite apoyar nuestra tesis- que el origen de esta institución se remonta, tan sólo, a los Proyectos de Apéndice de 1900 y de 1928, y queda claro en ellos que lo importante era atender al viudo en sus necesidades. Hasta esa época, lo relevante era el grupo familiar y, para cubrir los intereses de éste, el Derecho civil vizcaíno ya contaba con su específico régimen económico matrimonial y con su sistema sucesorio de troncalidad. Por tanto, la intención del legislador al concebir el usufructo vidual, ya desde los albores del siglo Xx, fue la de proteger la débil posición económica del viudo, lo que puede servirnos para respaldar aún más su carácter sucesorio-patrimonial.

Una cuestión que se plantea por la doctrina es si esta posición del viudo como usufructuario legal puede permitirnos catalogarlo como sucesor forzoso. En este sentido, el artículo 53 de la Ley vasca ${ }^{15}$ no incluye al cónyuge en

\footnotetext{
${ }^{13}$ Vid. Angoitia Gorostiaga, V. y Galicia Aizpurúa, G., «Las legítimas y la libertad de disposición en la Ley del Derecho civil del País Vasco» en VV.AA., Derechos Civiles de España, Volumen I, Ed. Aranzadi. 2000, p. 396.

${ }^{14}$ Como ocurre en el caso del derecho expectante de viudedad en Aragón. Recordemos, en este sentido, que el artículo 89 de la Ley aragonesa 2/2003, de 12 de febrero, de régimen económico matrimonial y viudedad, dispone que «la celebración del matrimonio atribuye a cada cónyuge el usufructo de viudedad sobre todos los bienes del que primero fallezca».

${ }^{15}$ Dice el artículo 53 de la LDCPV que «la sucesión forzosa, sin perjuicio de lo dispuesto para la troncalidad, se defiere por el siguiente orden:// 1. A los hijos, incluso los adoptivos, y demás descendientes.// 2. A los padres y demás ascendientes».
} 
la relación de sucesores forzosos, a diferencia de lo que hace el Código civil en su artículo 807. Sin embargo, no hemos de olvidar que el artículo 58 se encuentra dentro del Capítulo II, del Título III, dedicado a la sucesión forzosa y que el artículo 69 -al hablar de la sucesión ab intestato- califica a estos usufructos en favor del viudo como derechos legitimarios.

En realidad estamos hablando de la existencia de unas limitaciones a la libertad de disponer ${ }^{16}$, como ocurre con las legítimas, o como sucede con la troncalidad ${ }^{17}$. Y es evidente que, si por ley, necesariamente, han de reservarse determinados bienes en favor de determinadas personas -aunque sólo sea en usufructo- es porque «forzosamente» éstos han de sucederle. En mi opinión, no cabe duda alguna de que la posición del viudo usufructuario es la propia de un sucesor forzoso puesto que es la Ley la que impone al causante la obligación de respetar ese derecho concebido en favor del supérstite.

Cosa distinta es que quepa calificarlo como «heredero» forzoso, como literalmente hace el Código civil ${ }^{18}$. En mi opinión, el artículo 53 de la Ley vasca, con la elusión del término «herencia» y su sustitución por el de «sucesión», daba cobertura suficiente para incluir, dentro de los sujetos relacionados en él, a aquellos sucesores forzosos que no tienen por qué tener la calificación de herederos ${ }^{19}$. En este sentido, hemos de tener en cuenta que el viudo, en Vizcaya, conforme al artículo 58, tiene derecho al usufructo sobre una parte de los bienes del causante; y que, en principio, el término «heredero» debe referirse al que sucede indefinidamente en los derechos y obligaciones del causante, lo que no ocurre en el caso del usufructo vidual aquí analizado, el cual únicamente atribuye al supérstite unos derechos sobre una cuota de todos los bienes del causante, pero no implica, paralelamente, la asunción de la sucesión en sus obligaciones.

\footnotetext{
${ }^{16}$ Así pasa también en el caso del usufructo de fidelidad navarro, ubicado dentro del Título que lleva el siguiente encabezamiento: «De las limitaciones a la libertad de disponer».

${ }^{17}$ Vid. Celaya Ibarra, A., «Comentarios al artículo 58 de la Ley del Derecho civil foral del País Vasco», en Comentarios al Código civil y Compilaciones forales, dirigidos por M. Albaladejo y Silvia Díaz Alabart, t. XxVI, Edersa, Madrid, 1997, p. 249.

${ }^{18}$ Dice el artículo 807 del Cc: «Son herederos forzosos:// 3. ${ }^{\circ}$ El viudo o viuda en la forma y medida que establece este Código». Pero, como acertadamente ha puesto de relieve Vallet de Goytisolo, J., «Comentarios al artículo 834 del Código civil», en Comentarios

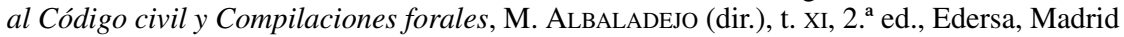
1982, p. 451, «el CC y la jurisprudencia, cuando denominan al cónyuge viudo "herederos forzoso" emplean la palabra heredero en un sentido muy general, lato e impropio». LACRUZ Berdejo, J. L., «Derechos de Sucesiones», en Elementos de Derecho Civil, V, Ed. Bosch, Barcelona, 1988, p. 501, señala que el viudo no es heredero, sino «sólo un sucesor ex lege», afirmación que podemos aplicar, también al caso vasco.

${ }^{19}$ Celaya IbarRa, A., «Comentarios al artículo 58 de la Ley del Derecho civil foral del País Vasco», en Comentarios al Código civil y Compilaciones forales, M. AlBALADEJo y Silvia Díaz Alabart (dirs.), t. XXVI, Edersa, Madrid, 1997, p. 249, se refiere al viudo y a los tronqueros como posibles sujetos que podían haber quedado abarcados dentro del artículo 53.
} 
En definitiva, a mi juicio, el usufructo legal del viudo contemplado en el artículo 58 es una institución sucesoria que atribuye al supérstite la condición de sucesor forzoso; lo que no implica que su posición sea la de un heredero. En mi opinión, sin embargo, tampoco nos encontraremos ante un legado, pues éste, a mi parecer, requiere la existencia de una disposición voluntaria por parte del causante que no se da en el caso de la atribución aquí examinada: lo que el artículo 58 recoge es una concesión de un derecho que corresponde al viudo por Ley. Independientemente de que exista sucesión testada o intestada, el supérstite gozará de este derecho. Por tanto, no nos encontraremos ni ante un heredero, ni ante un legatario en sentido estricto. La figura del viudo titular del usufructo legal prevista en este artículo es la propia de un sucesor cuyo derecho es de características diferentes, tanto al que corresponde a un heredero - puesto que, entre otras cosas, no asume todos los derechos y obligaciones del causante-, como al del legatario -ya que se trata de un derecho atribuido directamente por la Ley-. Podemos decir, simplemente, que es un sucesor legitimario ${ }^{20}$.

\section{B. Requisitos del usufructo vidual legal}

\section{B.1. LA SUBSISTENCIA DEL MATRIMONIO O DE LA PAREJA DE HECHO}

El artículo 58 de la Ley del Derecho civil del País Vasco determina que es el cónyuge viudo el que tiene el usufructo que en el mismo artículo se regula. Actualmente, y desde la entrada en vigor de la Ley 2/2003, deberemos entender que el precepto ha sido tácitamente modificado en el sentido de ampliar el ámbito personal de la titularidad del derecho también a los miembros supérstites de las parejas estables. Hasta ese momento podíamos considerar que el requisito sine qua non para ser titular de este derecho era el de la existencia de matrimonio en el momento del fallecimiento del consorte, lo que implicaba no sólo que no gozaban de ese derecho las parejas estables, sino también que no podían ser titulares de él los cónyuges cuyo matrimonio hubiera sido declarado nulo o hubiera sido disuelto mediante resolución judicial favorable al divorcio.

Hoy por hoy, sin embargo, el miembro supérstite de la pareja estable puede considerarse titular del usufructo vidual, siempre y cuando ésta no se

${ }^{20}$ De derecho legitimario, califica el artículo 69 de la Ley del Derecho civil foral vasco, al recogido en el artículo 58. CELAYA IBARRA, A., «Comentarios al artículo 58 de la Ley del Derecho civil foral del País Vasco», en Comentarios al Código civil y Compilaciones forales, M. Albaladejo y Silvia Díaz Alabart (dirs.), t. XXvi, Edersa, Madrid, 1997, p. 251, se refiere a la legítima vidual, y Angoitia Gorostiaga, V. y Galicia AizPurúa, G., «Las legítimas y la libertad de disposición en la Ley del Derecho civil del País Vasco» en VV.AA., Derechos Civiles de España, Volumen I, Ed. Aranzadi. 2000, p. 396, hablan de «la legítima usufructuaria atribuida al cónyuge supérstite en el art. 58». 
hubiera extinguido, de forma previa al fallecimiento de uno de sus miembros, por alguna de las causas previstas en el artículo 18 de la Ley 2/2003, es decir, por común acuerdo de sus miembros, por decisión unilateral de uno de ellos comunicada fehacientemente al otro o por matrimonio de cualquiera de los componentes de la pareja con otra persona distinta.

La aseveración de que es necesario que, en caso de matrimonio, éste estuviera vigente en el momento del fallecimiento del causante, se ve, además, ratificada por lo dispuesto en el artículo 59 de la misma Ley cuando señala que «carecerá de derechos sucesorios en la herencia de su consorte el divorciado (...)». Podemos, por tanto, afirmar que al fallecimiento del causante, el supérstite debía estar unido a él por un vínculo matrimonial que no hubiera sido disuelto, o por una relación de pareja de hecho que no se hubiera extinguido por causa distinta de la muerte o matrimonio entre sus dos miembros.

Al igual que ocurre en otros ordenamientos jurídico-civiles del Estado, también aquí podemos defender la posibilidad de que iniciada la acción de nulidad o de divorcio por uno de los cónyuges, los herederos, como interesados, podrán mantenerla a los solos efectos de que se determine la inexistencia del derecho del viudo al usufructo. Cierto es que, al respecto, nada dice la legislación foral vizcaína ${ }^{21}$; sin embargo, en el caso de la nulidad, podemos fundamentar el ejercicio de la acción -incluso sin la existencia previa de la iniciativa del premuerto ${ }^{22}$ - en la legitimación que para este supuesto atribuye el artículo 74 del Código civil «a cualquier persona que tenga interés directo y legítimo en ella (...)», salvo en los supuestos de nulidad en los que el propio Código, en su artículo 75, atribuye legitimación exclusiva-

\footnotetext{
${ }^{21}$ Cosa que, por ejemplo, sí hacía el artículo 335 de la Ley de sucesiones catalana que determina que «si al fallecer el causante, hay pendiente una demanda de nulidad matrimonial, divorcio o separación, salvo que ya haya habido reconciliación entre los cónyuges, los herederos llamados en defecto del cónyuge pueden seguir ejerciendo las acciones planteadas y, si lo hacen, deben esperar al resultado de la sentencia definitiva para mantener o para negar al cónyuge sobreviviente el derecho a suceder». En esa misma línea podemos considerar que también en el caso vizcaíno si se hubiera entablado la acción antes de la muerte de uno de los cónyuges, el derecho del otro deberá quedar en suspenso hasta que recaiga la sentencia definitiva.

${ }^{22}$ No obstante, en el caso de que la acción sea entablada directamente por los herederos tras el fallecimiento del causante, deberemos tener en cuenta que será de aplicación lo dispuesto en el artículo 79. Por tanto, si el supérstite contrajo el matrimonio de buena fe, la declaración de nulidad no podrá invalidar el efecto ya producido con la muerte de su cónyuge: su derecho al usufructo vidual ya habrá nacido y, en consecuencia, ese efecto no podrá anularse. De la misma opinión, respecto al derecho común, es VALLET DE GOYTISOLO, J., «Comentarios al artículo 807 del Código civil», en Comentarios al Código civil y Compilaciones forales, M. Albaladejo (dir.), t. XI, 2. ${ }^{\text {a }}$ ed., Edersa, Madrid, 1982, p. 47, cuando afirma que «no puede estimarse con derecho a la cuota vidual el cónyuge que de buena fe hubiere contraído matrimonio declarado nulo, salvo si la nulidad no fuere declarada hasta después del fallecimiento del otro cónyuge».
} 
mente al cónyuge sobreviviente -supuesto de la falta de edad o del error, coacción o miedo grave-. Y, en el caso del divorcio, un supuesto de justicia material aconseja permitir la continuación por los herederos de la acción entablada por el premuerto, con el único fin de resolver las cuestiones de índole patrimonial que puedan derivarse de la declaración de la existencia de causa de divorcio ${ }^{23}$.

\section{B.2. LA NO SEPARACIÓN}

Dispone el artículo 59 de la Ley del Derecho civil del País Vasco que «carecerá de derechos sucesorios en la herencia de su consorte (...) el cónyuge separado por causa a él imputable» ${ }^{24}$. Tenemos, por tanto, que no sólo la subsistencia del matrimonio es un requisito esencial para poder acceder al usufructo vidual, sino que también será necesario que no exista una separación entre los cónyuges de la que sea culpable el supérstite ${ }^{25}$.

${ }^{23}$ Vid., en este sentido, para el caso aragonés, a SANCho Rebullida, F. A. y De Pablo Contreras, P., «Comentarios a los artículos 72 a 88 (La viudedad)» en Comentarios a la Compilación del Derecho Civil de Aragón, Delgado Echeverría, J. (dir.), DGA, vol. II, Zaragoza, 1993, pp. 860 y 861 . También hay que considerar que, con relación al Derecho común, la anterior redacción del artículo 835 del Código civil, cuando hablaba del derecho del viudo al usufructo del tercio de mejora, señalaba que «cuando estuvieren los cónyuges separados en virtud de demanda, se esperará al resultado del pleito». Es decir, que parece que se permitía que, en los casos de separación, se «mantuviera» la acción entablada por uno de los cónyuges una vez fallecido el otro, a los solos efectos de determinar si el supérstite podía acceder al usufructo. Lo cual nos podría servir de fundamento para defender el mantenimiento de la acción -también en los casos de divorcio- por los herederos que pudieran estar interesados en el resultado del pleito, teniendo en cuenta que, a nuestro entender, a los efectos del Derecho foral, sigue teniendo relevancia la culpabilidad del cónyuge en la causa de separación. Vid. LACRUZ BERDEJO, J. L., en «La legítima del cónyuge viudo», Elementos de Derecho Civil V. Derecho de Sucesiones, Ed. Bosch, Barcelona, 1988, p. 502.

${ }^{24} \mathrm{Al}$ igual que ocurre con el divorcio, la separación a que se refiere el precepto únicamente es viable en los casos de relación conyugal. Por tanto, las afirmaciones que a continuación realizamos deben reconducirse exclusivamente a ese ámbito. Si el vínculo existente es el propio de una pareja de hecho de las reguladas por la Ley 2/2003 (que recordemos que también abarca a los homosexuales), bastará -conforme a su artículo 18- con el acuerdo de sus miembros o con la decisión unilateral de uno de ellos comunicada fehacientemente al otro, para que la relación se entienda extinguida y, por tanto, no se acceda al usufructo legal de viudedad. Insisto, no obstante, en la necesidad de que el legislador proceda a dar nueva redacción a todos los preceptos de la Ley del Derecho Civil Foral del País Vasco afectados por la Ley 2/2003 de 7 de mayo, en aras de la seguridad jurídica.

${ }^{25}$ En mi opinión, la desaparición de las causas de separación en el Código civil tras la reforma llevada a cabo por la Ley 15/2005, no debe afectar al ámbito que estamos analizando, puesto que el legislador foral, al redactar el artículo 59 de la Ley 3/1992, tuvo en consideración, precisamente, la redacción del Código civil vigente en aquel momento. En consecuencia, si la separación ha sido provocada por el comportamiento «culpable» de uno de los cónyuges, esta realidad determinará que su causante -pero sólo él- quedará excluido del 
En línea similar, el artículo 834 del Código civil, antes de ser reformado por la Ley 15/2005, establecía que «el cónyuge que al morir su consorte no se hallare separado o lo estuviere por culpa del difunto (...) tendrá derecho al usufructo (...)». Vemos, por tanto, que conforme al Derecho que regía en el territorio común antes de la mencionada reforma, en caso de separación, el supérstite no culpable de ésta podía conservar el usufructo legal. No obstante, podemos deducir una importante diferencia en la redacción de ambos preceptos: en mi opinión, mientras que el Código civil impedía el acceso al derecho no sólo al cónyuge responsable de la separación, sino también a aquellos que se encontraban separados sin que mediara culpabilidad de ninguno de ellos, en la Ley vasca sólo se excluye del usufructo a aquel a quien se puede imputar la causa que ha motivado la separación. Es decir, la Ley 3/1992 va a permitir acceder al derecho a los cónyuges separados siempre y cuando no exista culpabilidad en el posible titular del usufructo; cosa que no sucedía en territorio común, donde el único que podía acceder al derecho en caso de separación era aquel que lo estaba por culpa del difunto: si no existía culpa de nadie pero existía separación, ninguno de los consortes podía ser titular, en territorio común, del usufructo vidual. La diferencia se ha acentuado más tras la Ley 15/2005, de 8 de julio, puesto que el Código civil, en la nueva redacción del artículo 834, establece que «el cónyuge que al morir su consorte no se hallase separado de éste judicialmente o de hecho, si concurre a la herencia con hijos o descendientes, tendrá derecho al usufructo del tercio destinado a mejora». Es decir, que, hoy por hoy, en territorio común, ningún cónyuge separado tendrá el derecho de usufructo, ni siquiera cuando la separación sea simplemente de hecho. Esta reforma es plenamente coherente con la ausencia de necesidad de alegar causa alguna para la separación y, por tanto, con la desaparición del concepto de «culpabilidad» en ella a esos efectos, pero, en mi opinión, como he defendido en nota al pie ${ }^{26}$, no afecta a que podamos considerar la posible culpabilidad de los cónyuges en la separación a los efectos de acceder o no al usufructo vidual en Vizcaya conforme al artículo 59 de la Ley foral.

Aunque nada dice este artículo 59 sobre la posibilidad del perdón o la reconciliación como instrumentos para evitar la exclusión del derecho, debemos entender que ambas fórmulas son posibles. Y ello porque el artículo 4 de la Ley vasca establece el principio de libertad civil en virtud del cual las leyes se entienden dispositivas. Lo único que prohíbe este precepto es «la renuncia» a los derechos derivados de la Ley en cuanto contraríen el interés o el orden público o perjudiquen a tercero. Y resultando que en el caso del

usufructo. A nuestro entender, esta remisión estática a las causas de separación determina que, para la calificación como culpable de un determinado comportamiento pueda seguir sirviendo de parámetro la relación de causas que recogía, antes de la reforma, el artículo 82 , ahora derogado.

${ }^{26}$ Vid. nota anterior. 
perdón o la reconciliación de una causa de exclusión del derecho no nos encontramos ante una renuncia, no podemos considerar aplicable el inciso final prohibitivo del precepto. Por tanto, podemos abogar por la posibilidad de perdonar, o reconciliarse, a los efectos de impedir que la separación entre en juego como causa impeditiva del usufructo. Lo que, en todo caso, resultará necesario es una prueba suficiente de que se ha producido la reunión de los cónyuges o la remisión unilateral por la parte ofendida.

La Ley vasca nada dice sobre si la separación que imposibilita la titularidad del usufructo vidual debe ser separación judicial, o es suficiente con una separación de hecho. La doctrina mayoritaria que interpretó el artículo 834 del Código civil en su anterior versión, entendió que una separación de facto no permitía fundar en ella con seguridad un efecto tan importante como privar del derecho a legítima al cónyuge sobreviviente ${ }^{27}$. Y fundamentaban esa opinión en la anterior dicción del artículo 835 que se refería al supuesto de que los cónyuges estuvieren separados en virtud de demanda y al caso del perdón o la reconciliación ${ }^{28}$. Además, consideraban que, siendo aplicables las causas de desheredación recogidas en el artículo 855, existía ya el correspondiente mecanismo para que, en los casos de separación de hecho en los que mediaba culpa de uno de los cónyuges, el otro pudiera excluirlo del usufructo $^{29}$. Hemos de decir, sin embargo, que en el caso vasco no existe un precepto como el modificado artículo 835 del Cc. Por otro lado, no encuentro un argumento definitivo en la legislación foral para negar que la separación de hecho, cuando es por causa imputable al supérstite, determine la exclu-

${ }^{27}$ Vid. LaCruZ Berdejo, J. L., en «La legítima del cónyuge viudo», Elementos de Derecho Civil V. Derecho de Sucesiones, Ed. Bosch, Barcelona, 1988, p. 502; también, DiEZ Picazo, L. y Gullón Ballesteros, A. en «La legítima y la mejora», Sistema de Derecho Civil, Volumen IV, (Derecho de Familia. Derecho de Sucesiones), Ed. Tecnos, Madrid, 8. ${ }^{\text {a }}$ ed., 2003, p. 421.

${ }^{28}$ La actual redacción del artículo 835 del Cc, según Ley 15/2005, ya no hace referencia a la separación en virtud de demanda y, en consonancia con la ausencia de culpabilidad en la separación, tampoco menciona el perdón sino tan sólo la reconciliación. En concreto dice que «si entre los cónyuges separados hubiera mediado reconciliación notificada al juzgado que conoció de la separación de conformidad con el artículo 84 de este Código, el sobreviviente conservará sus derechos».

${ }^{29}$ El artículo 855 permite desheredar al cónyuge además de por haber sido condenado por haber atentado contra la vida del testador, ascendientes o descendientes, o por haberlo acusado calumniosamente de un delito con pena grave, obligarlo a cambiar o a hacer testamento, impedirle hacerlo, o revocarlo utilizando amenaza, fraude o violencia, ocultar o alterar el que ya hubiese hecho o no prestarle las atenciones debidas en caso de tratarse de un discapacitado, también por haber incumplido grave o reiteradamente los deberes conyugales, por incurrir en causa de privación de la patria potestad, por haber negado alimentos al hijo o al cónyuge, o por haber atentado contra su vida si no hay reconciliación. De todas maneras, la mencionada interpretación doctrinal hoy en día ha quedado sin fundamento al establecer claramente el actual artículo $834 \mathrm{del} \mathrm{Cc}$ que el derecho al usufructo no corresponde tampoco a los cónyuges separados de hecho. 
sión de su derecho. El tenor de la norma vasca no distingue entre los dos tipos de separación que pueden darse y, en consecuencia, una interpretación literal del artículo 59 de la Ley 3/1992 debe conducirnos a entender que también la separación de hecho debe provocar que el derecho no llegue a nacer si ésta es imputable al posible titular del usufructo ${ }^{30}$. Además, los supuestos de desheredación del artículo 855 no tienen por qué quedar reducidos a los casos de separación de hecho, sino que pueden perfectamente aplicarse a aquellos otros en los que no produciéndose ésta, concurren en el consorte las condiciones que el artículo señala para poder quedar al margen del derecho por voluntad del testador.

Por las mismas razones alegadas para el caso del ejercicio de las acciones de divorcio o de nulidad, debemos también entender que los herederos se encuentran legitimados para mantener la acción de separación entablada por su causante, a los únicos efectos de determinar si subsiste o no el derecho del viudo, lo que, en definitiva, dependerá de la culpabilidad o no del supérstite en la separación.

\section{B.3. NO TENER UN HIJO FUERA DEL MATRIMONIO, O DE LA RELACIÓN DE PAREJA, DURANTE SU VIGENCIA}

El artículo 58 de la Ley 3/1992, en su último párrafo establece, entre otras, como causa de extinción del derecho de usufructo del cónyuge viudo el tener, «durante el matrimonio (...) un hijo no matrimonial» ${ }^{31}$. El precepto no refiere esa causa como determinante del no nacimiento del derecho para el supérstite, sino como provocadora de su extinción. Es decir, la norma parece admitir que, en este caso, el derecho ha nacido con el fallecimiento del consorte y que se extingue como consecuencia de tener ese hijo. Sin embargo, hemos de considerar que el supuesto que estamos analizando úni-

\footnotetext{
${ }^{30}$ No olvidemos, por ejemplo, que también en la Compilación foral navarra, conforme a la Ley 254, la separación de hecho, en determinados casos, da lugar a la exclusión del usufructo de fidelidad. En definitiva, no encuentro un argumento esencial para negar esta posibilidad, tampoco en el caso vasco. Donde la Ley no distingue -y el artículo 59 de la Ley 3/1992 no lo hace- no tenemos por qué distinguir nosotros. Por otro lado, hoy se llega a la misma conclusión en territorio común con el actual artículo 834 del Cc; la separación de hecho, en los lugares regidos por esa norma, provoca el mismo efecto que la judicial: la exclusión del posible usufructo vidual.

${ }^{31}$ Conforme a la equiparación efectuada entre la pareja de hecho y el matrimonio, en el ámbito sucesorio, por el artículo 9 de la Ley 2/2003, deberemos entender que, en el primero de estos casos, no se accederá al usufructo vidual por tener durante la vigencia de la pareja de hecho -es decir, en el lapso de tiempo que media entre la inscripción en el Registro constituido al efecto y su extinción por muerte de uno de sus miembros- un hijo con otra persona. Todas las referencias que en este apartado se realicen al matrimonio, o a los cónyuges, deben considerarse hechas también a la pareja de hecho, o a sus miembros, teniendo en cuenta lo anterior.
} 
camente puede tener lugar en vida de ambos cónyuges, pues entre sus presupuestos se encuentra el de que el hijo se tenga «durante el matrimonio», por lo que hemos de considerar errónea su ubicación dentro de las causas de extinción. En realidad, nos hallamos ante un requisito para poder acceder al derecho: el supérstite no debe haber tenido durante la vigencia de su matrimonio un hijo de otra persona diferente a su cónyuge y, si lo hubiera tenido, el derecho no llegará a nacer, salvo que -como el propio precepto indica- «el testador haya dispuesto otra cosa», perdonando la causa de exclusión en la que ha incurrido su consorte.

\section{B.4. NO INCURRIR EN CAUSAS DE INDIGNIDAD PARA SUCEDER}

Al hablar de la naturaleza del usufructo vidual contemplado en el artículo 58, hemos concluido que es sucesoria. Sobre el particular no existen discrepancias doctrinales. Y siguiendo el criterio que hemos mantenido en este trabajo, a esa misma consecuencia tenemos que llegar: este usufructo nace con la muerte del cónyuge, o con la del compañero de la pareja; y es ese origen en el fallecimiento del causante lo que determina su naturaleza.

Partiendo de ello tenemos que afirmar la plena aplicación de las causas de indignidad como determinantes de la incapacidad para adquirir el derecho. La Ley vasca nada dice sobre este tema ${ }^{32}$, pero por la aplicación supletoria del Código civil, con fundamento en el artículo 3 de la Ley 3/1992, así lo debemos entender.

En consecuencia, debemos acudir al artículo 756 del Código civil para ver qué causas de las allí relacionadas pueden tener vigencia en el caso que nos ocupa. Pasamos a continuación a analizarlas.

II. B.4.a) El abandono, prostitución o corrupción de los hijos

Dice el artículo 756 del Código civil que son incapaces de suceder por causa de indignidad «los padres que abandonaren, prostituyeren o corrompieren a sus hijos». El precepto está pensando en la incapacidad de suceder del padre en la herencia del hijo abandonado, prostituido o corrompido. Es

\footnotetext{
${ }^{32}$ Pocas referencias hace la Ley del Derecho civil del País Vasco a las causas de indignidad a lo largo de su articulado. Entre ellas podemos destacar la recogida en el artículo 48.6 cuando se dice que el poder testatorio se extinguirá «por incurrir el comisario para con el causante o sus descendientes, en alguna de las causas que dan lugar a la indignidad para suceder». Esta previsión se debe, sin duda, al hecho de que el poder testatorio no confiere la condición de sucesor y es por ello por lo que la norma vasca se ve en la obligación de clarificar que, pese a ello, también se aplican al comisario como determinantes de la extinción del poder que se le ha otorgado. En el supuesto de los sucesores nada dice la norma pues considera que su aplicación no debe plantear duda alguna: da por sentado que deben regir las mismas para determinar la incapacidad para suceder.
} 
decir, es indigno de suceder el padre al hijo si con él se hubiera comportado de tal manera.

En otras instituciones viduales que -aunque de naturaleza sucesoriarecogen importantes componentes familiares ${ }^{33}$, es posible defender la aplicación de esta causa como determinante de la incapacidad para adquirir el usufructo vidual. Sin embargo, en el caso presente, entendemos que prima el carácter patrimonial sobre el familiar. Nos hallamos ante una institución puramente sucesoria y, por tanto, resultan plenamente trasladables a ella los conceptos genéricos de indignidad y las reglas habituales para su aplicación. Cierto es que el artículo 58, en su último párrafo, recoge, entre las causas de extinción de este usufructo, supuestos como las nuevas nupcias o la unión marital con otra persona, o el haber un hijo fuera del matrimonio. Igualmente, el artículo 59 excluye del derecho a quien se halle separado del cónyuge por causa a él imputable. Sin embargo, todos estos comportamientos inciden en la fidelidad del supérstite con respecto al causante: son causas que vinculan directamente a los cónyuges entre sí, y no como miembros de una familia más amplia. En ninguno de ellos se vincula a los hijos o descendientes. El contraer nuevas nupcias o unirse maritalmente con otra pareja se contempla como determinante de la extinción del usufructo vidual en cuanto dichas conductas pueden implicar la desaparición de una posible necesidad económica y, en todo caso, una falta de «fidelidad» a la memoria del causante. Y en este segundo sentido también debe entenderse que el tener un hijo fuera del matrimonio ${ }^{34}$ sea contemplado como causa extintiva. En cuanto a la separación $^{35}$, se prevé como excluyente del derecho en la medida que se deba a un comportamiento culpable del supérstite con respecto al fallecido; en ella se valora la relación de los cónyuges entre sí. Por tanto, en todas las conductas apuntadas, no se valora el comportamiento del supérstite con respecto a los hijos, sino con respecto al causante.

En esa línea, en mi opinión, debe mantenerse que esta causa de incapacidad para suceder no resulta aplicable al viudo para determinar la exclusión de su legítima, dado que nos hallamos ante una institución sucesoria cuya

${ }^{33}$ Así, por ejemplo, en el caso navarro entiendo que es posible considerar que el padre que abandona, prostituye o corrompe a su hijo no sólo es indigno de suceder a éste, sino que también lo es de adquirir el usufructo de fidelidad de su cónyuge, pues esta institución no pretende únicamente proteger en el ámbito patrimonial al viudo, sino que busca también concederle medios para que pueda continuar ejerciendo la autoridad familiar; y difícilmente se hace acreedor de ella quien es capaz de corromper, prostituir o abandonar a un miembro de la familia, como es el hijo.

${ }^{34} \mathrm{O}$ de la relación de pareja de hecho.

${ }^{35}$ Recordemos que, en mi opinión, la separación aquí contemplada sólo es causa determinante de que el derecho no llegue a nacer para el caso de que exista un vínculo matrimonial. En las parejas de hecho bastará el acuerdo de sus miembros o la comunicación fehaciente de uno de ellos al otro de su decisión de dar por extinguida la relación para que se produzca ese mismo resultado. 
finalidad es la de protegerlo de sus posibles necesidades económicas. A diferencia de lo que sucede en otros derechos forales, el usufructo vidual en Vizcaya no se concibe como un instrumento para el mantenimiento de la cohesión y la unidad familiar ${ }^{36}$, sino como una fórmula para cubrir las necesidades patrimoniales del viudo.

II. B.4.b) La condena en juicio por atentar contra la vida del cónyuge, compañero de la pareja de hecho, descendientes o ascendientes

Dice el número 2 del artículo 756 del Código civil que es incapaz de suceder por causa de indignidad «el que fuere condenado en juicio por haber atentado contra la vida del testador, de su cónyuge, descendientes o ascendientes».

En lo que aquí nos afecta, la condición de testador o causante coincide con la de consorte, o pareja de hecho, del que tiene que suceder, razón por la cual ambas referencias quedan reducidas únicamente a la de cónyuge o compañero en la relación estable.

Deberemos entender que la condena a que se refiere este precepto debe venir impuesta por una sentencia que haya adquirido firmeza. En dicha resolución se debe condenar al supérstite por haber atentado contra la vida del cónyuge o compañero, de sus ascendientes o de sus descendientes, sean éstos comunes o no lo sean. En todo caso, existiendo esa sentencia firme de condena, el viudo no podrá adquirir el usufructo a que se refiere el artículo 58. $\mathrm{Si}$ esa firmeza se produce con anterioridad al fallecimiento del causante, es obvio que el supérstite no podrá entrar en el disfrute de los bienes, puesto que la incapacidad para ello se manifiesta con anterioridad a la apertura de la sucesión.

El problema podría plantearse en aquellos supuestos en los que esa firmeza tiene lugar con posterioridad a la muerte. Para resolver esa cuestión el artículo 758 del Código civil dispone que «(...) se esperará a que se dicte la sentencia firme (...)». Es decir, que existiendo un procedimiento contra el supérstite por atentar contra la vida de su consorte, compañero, ascendientes o descendientes, iniciado con anterioridad al fallecimiento del causante, producido éste, deberemos esperar al momento en que recaiga sentencia firme a los efectos de valorar la capacidad para suceder. Hasta ese momento deberá entenderse que el derecho queda en suspenso. En mi opinión, por tanto, tam-

${ }^{36} \mathrm{El}$ que el usufructo vidual vizcaíno no se contemple como universal es una manifestación clara de que lo que se pretende no es mantener la unidad o la cohesión del patrimonio familiar -como sucede por ejemplo en el caso navarro o en el aragonés-, sino defender al viudo ante una posible situación de desvalimiento o de pérdida de nivel de vida que pudiera ocasionarse como consecuencia del fallecimiento de su consorte. Si se hubiera pretendido mantener dicha unidad se hubiera atribuido también el usufructo sobre la totalidad y no sólo sobre una parte. 
bién en estos casos, se incurre en una causa de indignidad que impide el acceso al derecho: el usufructo vidual no llega a nacer porque no se tienen los requisitos necesarios para ello.

Además, de la interpretación conjunta de los artículos 756.2. ${ }^{\circ}, 758$ y 760 del Código civil, debemos extraer la misma conclusión en relación con los atentados contra la vida del causante $-\mathrm{o}$ de los ascendientes o descendientes de éste, producidos antes de su muerte- que dan lugar a un procedimiento que se inicia tras su fallecimiento. En tales supuestos, la incapacidad está latente en el cónyuge, o miembro de la pareja, que atentó contra aquéllos y mientras no recaiga sentencia firme también su derecho debe entenderse que se encuentra en suspenso. Una vez se dicte ésta quedará aclarado si era incapaz o no lo era. Y, si lo era y entró indebidamente en posesión de los bienes, deberá -conforme a lo dispuesto en el artículo 760 del Código civil- devolverlos con todos sus frutos, rentas y accesiones: el que atentó contra la vida de su consorte o compañero -o ascendientes o descendientes de éste- es incapaz de suceder desde el mismo momento en que ejecutó su atentado ${ }^{37}$. Y esto es lo que provoca que, si finalmente acaba recayendo sentencia firme condenatoria, deba restituir todo lo percibido. En definitiva, tampoco en estos casos se reunirán los requisitos necesarios para adquirir el usufructo y, por tanto, el derecho a éste tampoco habrá llegado a nacer ${ }^{38}$.

\section{B.4.c) La condena por acusación calumniosa contra el premuerto}

Dice el artículo 756.3. ${ }^{\circ}$ que es incapaz de suceder «el que hubiese acusado al testador de delito al que la Ley señale pena no inferior a la de presidio o prisión mayor, cuando la acusación sea declarada calumniosa».

El vigente Código penal ya no recoge las penas de presidio o prisión mayor, sino que habla de penas graves, menos graves y leves. Su Disposición

${ }^{37}$ A mi juicio esto es así: si recae sentencia condenatoria, dicha resolución determinará que el viudo era incapaz desde el mismo momento en que atentó. Esta opinión parece compartirla Albaladejo García, M., «Comentarios al artículo 756» en Comentarios al Código civil y Compilaciones forales, M. AlBaladeJo (dir.), t. X, vol. 1. ${ }^{\circ}$, pp. 201-ss. Sin embargo, Diez Picazo, L. y Gullón Ballesteros, A. en «La delación de la herencia», Sistema de Derecho Civil, Volumen IV, (Derecho de Familia. Derecho de Sucesiones), Ed. Tecnos, Madrid, 8. ${ }^{\text {a }}$ ed., 2003, p. 308, manifiestan que «la indignidad surge de la condena (...), no del hecho de haber atentado»; y la misma idea parecen compartir HERNÁNDEZ GIL y VALLET DE Goytisolo, según cita de Albaladejo, op. cit., p. 201.

${ }^{38}$ En mi opinión, el único supuesto que no funcionaría propiamente como una causa determinante de que el derecho no llegue a nacer es el de los atentados contra la vida de los ascendientes o descendientes del cónyuge, o pareja, llevados a cabo tras el fallecimiento de éste. En tales supuestos, el viudo habrá entrado ya en posesión de los bienes usufructuados puesto que era capaz en el momento de la apertura de la sucesión. El posterior atentado contra la vida de los ascendientes o descendientes del premuerto no habrán impedido su acceso al usufructo. 
Transitoria Séptima determina que, la pena de prisión mayor, a la que se refiere el artículo 756.3. ${ }^{a}$ del $\mathrm{Cc}$, debe ser sustituida por la de prisión de tres a ocho años. Por ello, actualmente, será indigno de suceder el que hubiese acusado calumniosamente al causante de un delito al que la Ley señale una pena grave de prisión de, al menos, tres años y hubiera sido condenado por ello mediante sentencia firme.

A mi entender, las calumnias del supérstite contra el premuerto deberán haberse producido en vida de éste, y deben haber dado lugar al ejercicio de las acciones penales por parte del afectado, o su representante legal, pues únicamente ellos se encuentran legitimados para entablar un procedimiento de esta naturaleza.

Si la sentencia de condena adquiere firmeza antes del fallecimiento del consorte o compañero, resulta evidente la carencia del supérstite de los requisitos necesarios para acceder al usufructo. Y si esa firmeza se produce con posterioridad a esa muerte, de acuerdo con el artículo 758 del Código civil, deberemos esperar a ese momento para calificar la capacidad. Por tanto, habiéndose entablado las acciones penales correspondientes por el calumniado, y habiendo éste fallecido antes de que hubiera recaído resolución firme, el usufructo de fidelidad del supérstite quedará en suspenso. Si, finalmente, se declara la existencia de las calumnias, ello supondrá que éste era incapaz de suceder desde el inicio ${ }^{39}$.

II. B.4.d) La ausencia de denuncia a la justicia de la muerte violenta del cónyuge o pareja

Dispone el número $4^{\circ}$ del artículo 756 del Código civil que es incapaz de suceder por causa de indignidad «el heredero mayor de edad que, sabedor de la muerte violenta del testador, no la hubiese denunciado dentro de un mes a la justicia, cuando ésta no hubiera procedido ya de oficio».

El precepto exige, para que exista causa de indignidad, que el supérstite conozca la muerte violenta de su cónyuge o compañero y que, además, no lo hubiera denunciado dentro del mes siguiente a la autoridad judicial, a menos que, antes de ese plazo, ésta ya hubiera procedido de oficio. Siempre nos encontraremos, por tanto, ante un comportamiento que se producirá tras el fallecimiento del causante. Y para que éste pueda tener algún tipo de trascendencia sobre la capacidad sucesoria del viudo, el artículo 758 del Cc establece una especialidad a la regla general de que debe atenderse al tiempo de la muerte de la persona de cuya sucesión se trate. Así, señala que, en estos

${ }^{39}$ Puesto que para emprender las acciones por calumnias sólo se encuentran legitimados el calumniado, o su representante legal, debemos entender que no es viable el ejercicio de las acciones una vez que el causante hubiera fallecido. Siempre se requerirá que el premuerto hubiera entablado en vida las acciones legales pertinentes -directamente o a través de su representante-. 
casos, tendremos que esperar a que transcurra el mes que tiene el cónyuge o compañero para denunciar los hechos. Por tanto, fallecido el causante por muerte violenta, deberemos dejar que transcurra un mes ${ }^{40}$; de esta forma $y$, si en ese mes ni se ha procedido de oficio ni el viudo ha denunciado la muerte, existirá incapacidad para suceder. Hasta que ese mes haya transcurrido su derecho estará en suspenso.

Podría darse la circunstancia de que el conocimiento que el supérstite tuvo de los hechos con anterioridad no se ponga de relieve sino después de que hubiera entrado en el disfrute de los bienes. En este supuesto deberá atenderse al artículo 760 del Código civil que impone la obligación de restituir los bienes con los frutos y rentas que hubiera percibido. En mi opinión, se trataría de un caso de ejercicio de un derecho que no se ha adquirido, puesto que el viudo era indigno por conocer y no denunciar la muerte violenta y, por tanto, no tenía capacidad para adquirir el usufructo de fidelidad ${ }^{41}$.

\section{B.4.e) La coacción al cónyuge, o compañero, para que otorgue testamen- to o lo modifique}

El apartado 5. ${ }^{\circ}$ del artículo 756 del Código civil dispone que es incapaz de suceder «el que con amenaza, fraude o violencia, obligare al testador a hacer testamento o a cambiarlo».

${ }^{40}$ Sobre que es el conocimiento de la muerte violenta por parte del indigno el que determina el inicio del plazo del mes para calificar el cumplimiento por parte de éste de su deber de denunciar, vid. STS 11-02-46, citada por PUIG BRUTAU, J. en Fundamentos de Derecho

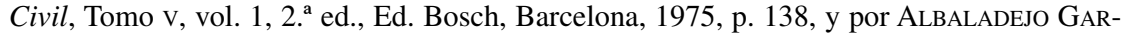
CíA, M., «Comentarios al artículo 756», en «Comentarios al Código civil y Compilaciones forales», dirigidos por M. Albaladejo, t. X, vol. 1. ${ }^{\circ}$, p. 232. No obstante, para fijar el momento hasta el que hemos de esperar para calificar su capacidad conforme al artículo 758 del Código civil, debemos remitirnos al instante de la muerte. Transcurrido el mes desde ese fallecimiento valoraremos la capacidad del cónyuge, o pareja, puesto que resulta necesario fijar un punto concreto de partida si no queremos que el derecho de usufructo pueda permanecer indefinidamente en suspenso. Vid. Albaladejo García, M., «Comentarios al artículo 758 del Código civil» en Comentarios al Código Civil y Compilaciones Forales, M. Albaladejo y Silvia Díaz Alabart (dirs.), t. X, vol. 1, Edersa, Madrid, 1987, p. 250. En definitiva, transcurrido el plazo de un mes desde la muerte del causante, cesará el periodo en el que el usufructo de fidelidad se encuentra en suspenso y, por tanto, habrá que decidir en ese momento si existe o no causa de indignidad. Si posteriormente se descubriera que el supérstite tuvo conocimiento de la muerte violenta dentro del plazo de ese mes a contar desde el fallecimiento del causante, procederá su consideración como indigno y, conforme al artículo 760 del Cc, deberá restituir los bienes, frutos y rentas que hubiera percibido.

${ }^{41}$ Otro supuesto diferente sería aquel en el que el conocimiento del viudo de que la muerte de su cónyuge, o pareja, se debió a causa violenta, se produce una vez ya ha entrado en el disfrute de su legítima. En tales casos, la indignidad no existirá en el momento del nacimiento del derecho, motivo por el cual el viudo habrá adquirido con plenitud el usufructo vidual (sin perjuicio de que, como veremos más adelante, proceda, en nuestra opinión, la extinción sobrevenida de esa fidelidad). 
En principio, podría parecer que este precepto está pretendiendo excluir del derecho a quienes utilizan subterfugios para que el causante les beneficie. Se trataría de influir en su voluntad mediante la utilización de ardides tales como la amenaza, el fraude o la violencia, con el fin de obtener una disposición testamentaria provechosa. En tal sentido, y puesto que el usufructo vidual recogido en el artículo 58 de la Ley 3/1992, es un derecho establecido por Ley, podríamos pensar que la presión que el supérstite haya podido ejercer sobre el premuerto no habrá incrementado el contenido de ese derecho y, por tanto, no deberá provocar su exclusión ${ }^{42}$.

Sin embargo, aun suponiendo que esto fuera así, también lo es que el cónyuge o pareja puede haber utilizado las mencionadas artimañas con el propósito de obtener unos beneficios añadidos a los concedidos por la Ley, tales como la concesión de un poder testatorio, el legado de un usufructo universal sobre los bienes del testador con fundamento en el artículo 61, o la atribución de determinados bienes dentro de la libertad de disposición que permite la propia Ley vasca, por ejemplo. Pues bien, en mi opinión, la utilización de tales medios con ese fin provocará la indignidad del supérstite y, en consecuencia, la carencia de requisitos necesarios para que se produzca la adquisición del usufructo vidual ${ }^{43}$. Ello siempre y cuando no haya existido perdón o reconciliación, de conformidad con el artículo 757 del Código civil.

Pero es más, las causas que la Ley vasca prevé como extintivas del derecho ya surgido inciden en comportamientos que el legislador parece entender que afectan a la fidelidad entre el premuerto y el supérstite: así, por ejemplo, el tener hijos no matrimoniales, antes o después de la relación que debe dar lugar al derecho; y, en cierta medida, también el contraer nuevas nupcias o convivir maritalmente con otra persona ${ }^{44}$. En la misma línea, la utilización de fraude, violencia o intimidación frente al cónyuge, o pareja, para que otorgue o modifique su testamento puede considerarse como una conducta que revela la poca confianza que merece el supérstite: quien es capaz de proceder de tal manera manifiesta frente al causante una ausencia absoluta de fide-

${ }^{42}$ De esta opinión, para el derecho aragonés, parece ser LATORRE MARTínEZ DE BAROJA, E., «Comentarios a los artículos 72 a 86», en Comentarios al Código civil y Compilaciones forales, M. AlbaladeJo (dir.), t. XXXIII, vol. 2. ${ }^{\circ}$, Edersa, Madrid, 1990, p. 348.

${ }^{43}$ Como dice Lacruz Berdejo, J. L., «Derechos de Sucesiones», en Elementos de Derecho Civil, V, Ed. Bosch, Barcelona, 1988, p. 81, la indignidad lleva consigo, para el sancionado, «la pérdida de la legítima: aunque lo niegue parte importante de la doctrina, así se desprende de su naturaleza y fundamento, no menos que del texto del artículo 761 (en tal sentido S. 28 febrero 1947)».

${ }^{44}$ En éstas podría también observarse un criterio basado en la consideración de la falta de necesidad económica del viudo provocada por la nueva relación: si el viudo se casa nuevamente o vive con otra persona, el legislador puede pensar que con ello quedarán ya cubiertas las necesidades que la legítima vidual pretende cubrir. 
lidad y, por tanto, debe quedar fuera de la adquisición de cualquier derecho sobre su patrimonio, incluso de los derechos legitimarios. En mi opinión, aun cuando no persiguiera con sus ardides la obtención de beneficios particulares, debe ser excluido del usufructo vidual en la medida en que su actitud revela la falta de confianza absoluta que merece y que es parte del fundamento de este derecho legitimario ${ }^{45}$.

\section{B.4.f) La coacción al testador para impedirle testar, forzarle a revocar el} testamento o su suplantación, ocultación o alteración

Afirma el número $6 .^{\circ}$ del artículo 756 del Código civil que es incapaz de suceder «el que por iguales medios -amenaza, fraude o violencia-impidiere a otro hacer testamento, o revocar el que tuviese hecho, o suplantare, ocultare o alterare otro posterior».

La motivación de esta causa de indignidad es coincidente con la del número anterior. Podría parecer que el legislador está pensando en aquellos casos en los que un sucesor del causante utiliza las mencionadas estratagemas con el fin de impedir que éste haga un testamento que pueda perjudicarle, o revoque otro otorgado anteriormente que le beneficiaba, o lo suplante, oculte o altere con el objeto de obtener un provecho propio ${ }^{46}$.

De la misma manera que en el supuesto precedente, podemos pensar en situaciones que, aunque no afecten directamente a la legítima del viudo, pueden alterar otros derechos que le puedan corresponder. $\mathrm{Y}$ en ese sentido, cabe imaginar un interés particular en influir sobre la voluntad del testador. Pero, al igual que en el caso anterior, y con independencia de la finalidad perseguida, en mi opinión, el cónyuge, o compañero, que ha traicionado la confianza del premuerto merece el castigo de la exclusión de su legítima vidual puesto que la concesión de este derecho legal está fundada,

${ }^{45}$ Hay que tener en cuenta, además, que la doctrina mayoritaria, en derecho sucesorio general, no considera necesaria la búsqueda de intereses particulares para que la indignidad entre en juego. Vid. Puig Brutau, J. en Fundamentos de Derecho Civil, t. v, vol. 1, 2. ${ }^{\text {a }}$ ed., Ed. Bosch, Barcelona, 1975, p. 140; Albaladejo García, M., «Comentarios al artículo 756», en Comentarios al Código civil y Compilaciones forales, M. Albaladejo, t. x, vol. 1. ${ }^{\circ}$, p. 233; o, Diez PiCazo, L. y Gullón Ballesteros, A. en «La delación de la herencia», Sistema de Derecho Civil, Volumen IV, (Derecho de Familia. Derecho de Sucesiones), Ed. Tecnos, Madrid, 8. ${ }^{\text {a }}$ ed., 2003, p. 309.

${ }^{46}$ Esta idea parece latir en la opinión de Latorre Martínez de BAROJA, E., «Comentarios a los artículos 72 a 86», en Comentarios al Código civil y Compilaciones forales, $\mathrm{M}$. AlbaladeJo (dir.), t. XXXIII, vol. 2. ${ }^{\circ}$, Edersa, Madrid, 1990, p. 348, cuando afirma que esta causa de indignidad sólo cabría entenderla aplicable al derecho de viudedad aragonés «si lo que se pretende con esa amenaza, fraude o violencia es obligar a cambiar el testamento para impedir la reducción de la viudedad (...)». 
en parte, en la relación de confianza y fidelidad que debe regir la relación de la pareja ${ }^{47}$.

II. B.4.g) La no prestación de atenciones debidas al cónyuge o compañero discapacitado

La Ley 41/2003 de 18 de noviembre ha introducido un nuevo apartado en el artículo 756 del Código civil. Se trata del número 7. En su virtud es incapaz de suceder «tratándose de la sucesión de una persona con discapacidad, las personas con derecho a la herencia que no le hubieren prestado las atenciones debidas entendiendo por tales las reguladas en los artículos 142 y 146 del Código Civil».

Encontrándonos ante un derecho de naturaleza sucesoria como es el usufructo vidual que estamos examinando, resultará que es indigno de adquirirlo el viudo de un discapacitado que en vida de éste no le hubiera dado el sustento, no le hubiera facilitado habitación, vestido o asistencia médica proporcional a su capacidad económica y a las necesidades del premuerto. En mi opinión, no será necesario que exista una sentencia de incapacitación, sino que bastará con que se dé, de facto, una situación de minusvalía que justifique la necesidad de obtener del consorte las correspondientes atenciones reguladas en los artículos 142 y ss. del Código civil. De incumplirse dichas obligaciones $-\mathrm{y}$, a mi juicio, aun cuando no exista una sentencia de condena contra el infractor-, cualquier interesado en la herencia del premuerto podrá ejercitar las acciones necesarias para que sea declarada la indignidad del supérstite con efectos desde el fallecimiento del causante.

\section{C. El objeto del usufructo vidual legal}

Como hemos visto, el artículo 58 de la Ley vasca establece que «el cónyuge viudo tendrá el usufructo de la mitad de todos los bienes del causante, si concurriere con descendientes o ascendientes.// En defecto de ascendientes o descendientes, tendrá el usufructo de dos tercios de todos los bienes». En este sentido, podemos afirmar que la Ley 3/1992, de 1 de julio, ha ampliado notablemente los derechos que concedía la Compilación, puesto que ésta sólo atribuía al cónyuge viudo el usufructo de la mitad de los bienes de libre disposición cuando no concurriera con hijos o descendientes legítimos. Ello suponía que, concurriendo con ascendientes, la extensión del usufructo de viudedad era mínima, puesto que, en aquel entonces, la legíti-

\footnotetext{
${ }^{47}$ Recordemos -como hemos hecho anteriormente- que para la doctrina mayoritaria, en derecho sucesorio general, no es necesaria la búsqueda de intereses propios para que la utilización de estos ardides provoquen que la causa de indignidad entre en juego. Vid. nota 44 anterior.
} 
ma de éstos era de cuatro quintas partes de la herencia, lo que determinaba que el usufructo legal del viudo, en tal caso, se redujera a una décima parte de los bienes del causante (la mitad de la quinta parte de libre disposición). Si concurría con los colaterales, la legítima vidual podía alcanzar a la mitad de todos los bienes (en caso de no existir bienes troncales), pero podía quedar reducida a la nada, si todos los bienes eran de esta naturaleza. Por otro lado, si la concurrencia era con hijos o descendientes legítimos, no se le atribuía derecho alguno, puesto que, en tal supuesto, se le consideraba suficientemente protegido con el régimen económico matrimonial de comunicación foral $^{48}$.

Con el régimen derivado del artículo 58, la situación cambia radicalmente. El cónyuge, existan o no hijos o descendientes, será titular del derecho ${ }^{49}$. Además, la extensión del usufructo no viene ya referida solamente a los bienes de libre disposición, sino que afecta a «todos los bienes del causante», razón por la cual su mayor amplitud es más que evidente; sobre todo si consideramos que, incluso el porcentaje sobre los bienes a los que se extiende, es también superior. A este respecto no hemos de olvidar que ahora, en concurrencia con ascendientes, el derecho abarcará la mitad de todos los bienes -frente a la décima parte de ellos a los que se extendía con el régimen compilatorio-. Y con relación a la concurrencia con los descendientes, frente a la carencia del derecho en la anterior situación, ahora se iguala el derecho al caso de que existan ascendientes, es decir, se extiende también a la mitad de los bienes del causante. Incluso en el supuesto más benigno de la Compilación -el de que todos los bienes relictos fueran no troncales y de libre disposición por inexistencia de herederos legitimarios-, la extensión del derecho era inferior pues abarcaba únicamente a la mitad de todos los bienes, frente a los dos tercios a los que, actualmente, se refiere el segundo párrafo del artículo 58. Y es que, como hemos insinuado, el hecho de que todos los bienes relictos sean troncales -como más adelante veremos- no va a impedir que sobre ellos se extienda el derecho de usufructo: la Ley señala una preferencia en la extensión del disfrute sobre aquellos que no tengan tal carácter, pero, en su ausencia, o siendo insuficientes, también los bienes del tronco pueden verse afectados por el derecho del viudo.

En definitiva, en la actualidad, si el supérstite concurre con descendientes o con ascendientes, su usufructo abarcará a la mitad de todos los bienes. Y si no existen descendientes o ascendientes que sean sucesores, el porcentaje de bienes afectados por el usufructo alcanzará los dos ter-

${ }^{48}$ Decía el artículo 26 de la Ley de 30 de julio de 1959 sobre la Compilación del Derecho civil foral de Vizcaya y Álava que «el cónyuge viudo tendrá el usufructo de la mitad de los bienes de libre disposición cuando no concurra con hijos o descendientes legítimos».

${ }^{49}$ Como hemos venido insistiendo, tal titularidad también corresponde al miembro «viudo» de la pareja de hecho. 
$\operatorname{cios}^{50}$. Este derecho es, además, independiente del régimen económico que rija el matrimonio. El viudo gozará de ese usufructo sobre la mitad -o sobre los dos tercios de todos los bienes del cónyuge premuerto- hayan pactado, o no, un régimen diferente al legal; y, en el primer caso, sea cual sea el contenido de ese régimen. Lo cual es importante, pues no hay que olvidar que la motivación fundamental por la que en la Compilación ${ }^{51}$ se excluía del usufructo al viudo cuando concurría con hijos o descendientes legítimos era que, en tal supuesto, conforme al régimen de comunicación foral, ésta continuaba y el viudo entraba en la posesión de la mitad de los bienes con ciertas opciones de representación, administración, e incluso de usufructo, sobre la otra mitad. No hay que olvidar tampoco, que el artículo 41 de la Compilación establecía un principio de inmutabilidad del régimen económico matrimonial una vez contraídas las nupcias, razón por la cual, si antes de la unión los cónyuges no hubieran elegido un régimen de bienes diferente al legal, era éste el que les debía regir. Ahora, sin embargo, la Ley 3/1992, de 1 de julio, ha consagrado el criterio de libertad civil para poder pactarlo o modificarlo antes o después de la celebración, motivo que hace posible que sean más los casos en los que el matrimonio regule su régimen económico de acuerdo a criterios diferentes a los establecidos por el régimen legal ${ }^{52}$.

${ }^{50}$ Recordemos que, conforme a lo dispuesto en los artículos 834 y ss. del Cc, en Derecho civil común, el viudo, si concurre con hijos o descendientes, tendrá el usufructo sobre el tercio destinado a mejora. Si la concurrencia se da con los ascendientes, se adquirirá el uso y disfrute de la mitad de la herencia. Y si no existen ni ascendientes ni descendientes, el usufructo alcanzará los dos tercios. Vemos, por tanto que el Derecho civil vizcaíno, en comparación con lo dispuesto en el Código civil, prima al viudo en el caso de que existan descendientes, ya que, en tal supuesto, le atribuye el usufructo sobre la mitad de todos los bienes de la herencia, frente al tercio de libre disposición afectado que recoge el Cc. En este sentido, Celaya Ibarra, A., «Comentarios al artículo 58 de la Ley del Derecho civil foral del País Vasco», en Comentarios al Código civil y Compilaciones forales, M. Albaladejo y Silvia Díaz Alabart (dirs.), t. XXVI, Edersa, Madrid, 1997, p. 252, considera que en Derecho civil vasco «debería haber alguna diferencia entre el caso de los descendientes y el de los ascendientes, pues en el primer caso, habiendo hijos, hay un régimen de comunicación, y el viudo entra en posesión de la mitad de todos los bienes, lo que no ocurre cuando no hay hijos y ésta fue seguramente la razón de que la Compilación no le concediera ningún derecho en el primer caso». No obstante, debemos recordar que esta redacción va a permitir la protección del viudo también en los casos en los que se haya pactado un régimen económico matrimonial diferente al legal de comunicación foral.

${ }^{51}$ Decía el artículo 41 de la Compilación que «el régimen de los bienes en el matrimonio, una vez contraído éste, es inmutable aun en el caso de pérdida o adquisición voluntaria o involuntariamente por parte del marido de la cualidad de vizcaíno infanzón».

${ }^{52}$ En este punto existe una diferencia entre las parejas de hecho y los matrimonios, dado que la Ley 2/2003, señala en su artículo 6 que, «en defecto de pacto expreso, los miembros de la pareja podrán adherirse a las cláusulas que con carácter general se establezca (...)». Es decir, debe jugar la voluntad de sus miembros para determinar cómo regular su régimen económico, pero no se establece la aplicación supletoria del régimen económico de comunicación foral. 
Pero, en definitiva -y en lo que aquí más nos importa-, mientras que con la Compilación un viudo con hijos o descendientes legítimos que hubiera pactado un régimen de separación de bienes no gozaba de protección, ni a través del régimen económico matrimonial, ni a través de un derecho legal de usufructo, con la Ley 3/1992, podrá usar y disfrutar de la mitad de todos los bienes de la herencia, posibilidad que, en mi opinión, es de alabar.

Más arriba hemos avanzado otra importante diferencia entre la actual configuración del usufructo legal a favor del viudo, previsto en el artículo 58 de la Ley del Derecho civil del País Vasco, y su anterior formulación de la Compilación: en ésta la determinación del objeto sobre el que se extendía el derecho se calculaba en atención a unos porcentajes a aplicar sobre los bienes de libre disposición. Por el contrario, en la actualidad se dice que el cónyuge viudo ${ }^{53}$ tendrá el usufructo de la mitad o de dos tercios «de todos los bienes» del causante. Esta nueva estructura del derecho nos va a permitir que incluyamos dentro del posible objeto del usufructo los bienes troncales. Mientras con el sistema previo a la Compilación la existencia de bienes de esta naturaleza podía reducir o impedir la materialización del derecho, puesto que sólo los bienes de libre disposición (entre los que no se encuentran los troncales) podían quedar afectados por el usufructo vidual, con la Ley 3/1992 su influencia sobre la extensión del derecho es nula: el derecho del viudo seguirá afectando a la mitad o al tercio del patrimonio del premuerto con independencia de que los bienes troncales superen esos porcentajes. Es decir, que esos bienes también pueden convertirse en objeto del usufructo. Eso sí, la Ley ha querido preservar el tronco en la medida que esa protección no afecte al derecho del viudo ${ }^{54} \mathrm{y}$, de esta forma, el tercer párrafo del artículo 58 ha dispuesto que «el usufructo recaerá en último lugar sobre los bienes troncales de ambas líneas del causante, en proporción al haber de cada una de ellas». Por ello, existiendo bienes no troncales suficientes el usufructo del viudo deberá recaer sobre ellos y, sólo en su ausencia, podrán afectarse los pertenecientes al tronco.

La Ley señala que tal afectación, si existen bienes de las dos líneas del causante, debe producirse «en proporción al haber de cada una de ellas». Es decir, que debe mantenerse un equilibrio en la protección del tronco paterno y materno del causante de forma tal, que no se privilegie a uno de ellos sobre

\footnotetext{
${ }^{53} \mathrm{Al}$ que deberemos entender asimilado, el miembro «viudo» de la pareja de hecho.

${ }^{54}$ Podemos decir que la nueva Ley ha modificado la escala de valores del derecho foral vizcaíno. Si antes lo esencial era el tronco, ahora es la protección del viudo. Se siguen manteniendo ciertas medidas legislativas de salvaguardia de la troncalidad pero ahora, a diferencia de lo que sucedía con la Compilación, se supeditan a la suficiente cobertura del viudo.
} 
el otro a la hora de dejarlo a salvo de la carga que pueda suponer el usufructo $^{55}$.

Y aún en el caso de que el tronco deba verse afectado por el derecho del viudo, la Ley busca fórmulas para intentar proteger su integridad. A esta intención, precisamente, responde el cuarto párrafo del artículo 58 cuando dice que «podrán los tronqueros conmutar el usufructo del cónyuge ${ }^{56}$ viudo, en cuanto afecte a los bienes troncales, por un capital en efectivo que será de su libre disponibilidad y no estará sujeto a reserva ni a devolución en los supuestos de extinción (...)». Es decir, se articula una fórmula legal que va a permitir que los parientes interesados en salvar la indemnidad del tronco puedan hacerlo: si ése es su deseo podrán sustituir los bienes del tronco que, en principio, podrían ser objeto del disfrute del supérstite por una cuantía en metálico que no se encontrará sujeta a ningún tipo de restricción sino que será de libre disposición para el viudo ${ }^{57}$.

Conforme a lo que dispone ese tercer párrafo del artículo 58, son los tronqueros los que pueden conmutar el derecho del viudo. Es decir, no se trata de un derecho de éste a exigir una sustitución del objeto del usufructo por una cuantía en metálico, sino en una opción que pertenece a los sucesores del causante en el tronco, ya sean ascendientes, descendientes o colaterales, y tengan la condición de herederos o de legatarios ${ }^{58}$. No obstante, esa posibi-

55 Parece razonable la opinión de CELAYA IBARRA, A., «Comentarios al artículo 58 de la Ley del Derecho civil foral del País Vasco», en Comentarios al Código civil y Compilaciones forales, M. Albaladejo y Silvia Díaz Alabart (dirs.), t. XXVI, Edersa, Madrid, 1997, p. 252, al considerar que si hay distintos sucesores troncales en la misma línea porque unos bienes proceden del abuelo y otros de la abuela, también habrá que dividir el usufructo en forma proporcional entre ellos.

${ }^{56} \mathrm{O}$ compañero en la pareja de hecho.

${ }^{57}$ Recordemos que el Código civil también incluye un fórmula para sustituir el usufructo sobre los bienes de la herencia por el pago de un capital, renta o producto de determinados bienes. En concreto, el artículo 839 del Código civil dispone que «los herederos podrán satisfacer al cónyuge su parte de usufructo, asignándole una renta vitalicia, los productos de determinados bienes, o un capital en efectivo (...)». Además de por la gama de posibilidades que ofrece este precepto -renta vitalicia, producto de determinados bienes o capital en efectivo-, y de la que carece el artículo vizcaíno que sólo habla de «capital en efectivo», ambos preceptos se diferencian en su finalidad. El artículo del Código civil pretende evitar la división del dominio en todo caso -vid. VALLET DE GoYTisolo, J., «Comentarios al artículo 839 del Código civil», en Comentarios al Código civil y Compilaciones forales, M. Albaladejo (dir.), t. XI, 2. ${ }^{a}$ ed., Edersa, Madrid, 1982, pp. 470-ss., mientras que el artículo 58 de la Ley foral sólo busca mantener la integridad del tronco y, por ello, únicamente refiere esta posibilidad al usufructo que afecte a los bienes troncales.

${ }^{58}$ Sobre la inclusión de los legatarios como titulares del derecho a solicitar la conmutación en el derecho común -a pesar del tenor literal del artículo 839 Cc que se refiere a «herederos»- vid. VALLET DE GoYTisolo, J., «Comentarios al artículo 839 del Código civil», en Comentarios al Código civil y Compilaciones forales, M. Albaladejo (dir.), t. XI, 2. ${ }^{a}$ ed., Edersa, Madrid, 1982, pp. 473-ss., y los autores por él citados. 
lidad no supone una carta en blanco para imponer su voluntad. En primer lugar, la Ley establece que esa facultad sólo les autoriza a sustituir el usufructo por una capital en efectivo. Es decir, a diferencia de lo que ocurre en el caso del artículo 839 del Código civil ${ }^{59}$, los tronqueros no pueden imponer al viudo la conmutación de su derecho de usufructo inicial por una renta vitalicia, ni por el producto que derive de determinados bienes, sino única y exclusivamente por un capital en efectivo. Por tanto, si no es esto último lo que se le ofrece, en mi opinión, el viudo podrá rechazar la sustitución. Y aun suponiendo que sea esto lo que se le ofrezca, no estará obligado a aceptar cualquier cuantía. De esta forma, si no existiera acuerdo sobre el importe del capital sustitutivo del usufructo, se deberá acudir al Juez para que sea él quien lo determine ${ }^{60}$.

La Ley nada dice sobre si los tronqueros, en caso de ser varios, deben o no actuar de común acuerdo para decidir sobre la sustitución del usufructo del viudo por un capital en efectivo. Sin embargo, la doctrina mayoritaria, referente al artículo 839 del Código civil, ha entendido que así debe $\operatorname{ser}^{61} \mathrm{y}$, con fundamento en ello, también se ha defendido que, en el caso vizcaíno,

${ }^{59}$ En opinión de Gullón Ballesteros, A., «El párrafo 3. ${ }^{\circ}$ del artículo 820 del Código civil», en Anuario de Derecho Civil, 1961, p. 889, en el sistema previsto en el Código civil, «los herederos forzosos proponen al viudo la conmutación, y éste se puede mostrar disconforme, no con ella ni con el medio de pago elegido para ello, sino con la valoración de su usufructo y del objeto por el que se le sustituye (...)», y, en «La conmutación del usufructo legal del cónyuge viudo», en Anuario de Derecho Civil, 1964, p. 606, después de manifestar su sintonía con MEZQuiTA DEL CACHO, pone de manifiesto cómo el mutuo acuerdo no se precisa para decidir la forma de pago.

${ }^{60}$ Como dice Celaya IBARRA, A., «Comentarios al artículo 58 de la Ley del Derecho civil foral del País Vasco», en Comentarios al Código civil y Compilaciones forales, M. ALBALADEJo y Silvia Díaz Alabart (dirs.), t. XXvi, Edersa, Madrid, 1997, p. 254, aunque los tronqueros no pueden imponer otra forma de pago diferente al capital en metálico, nada impide que acuerden con el viudo la sustitución del usufructo por una renta o por los frutos de determinados bienes, posibilidad que, no obstante, no será exclusiva de los tronqueros, sino que cabrá en cualquier caso. En realidad, se tratará de obtener una renuncia del supérstite a su derecho a cambio de la atribución que se le haga de un bien, dinero o renta o de la obtención de cualquier otra contraprestación, con el fin de mantener la unidad del dominio sobre uno o varios bienes. Y esta posibilidad de renuncia es posible en todos los usufructos viduales contemplados en los ordenamientos civiles que conviven en España.

${ }^{61}$ Vid. Vallet De Goytisolo, J., «Comentarios al artículo 839 del Código civil», en Comentarios al Código civil y Compilaciones forales, M. Albaladejo (dir.), t. XI, 2. ${ }^{\text {a ed., }}$ Edersa, Madrid, 1982, pp. 482-ss. quien considera que la necesidad de los herederos de actuar de común acuerdo no deriva directamente de los términos empleados por el artículo 839 del Código civil cuando habla de que «los herederos podrán satisfacer al cónyuge su parte de usufructo (...) procediendo de mutuo acuerdo»-pues este mutuo acuerdo se refiere al de los herederos con el cónyuge- sino que dimana de los principios generales. GuLLón BALLESTEROS, A., «La conmutación del usufructo legal del cónyuge viudo», en Anuario de Derecho Civil, 1964, p. 601 y, fundamentalmente, pp. 606-ss., ha entendido, sin embargo, que es posible el ejercicio individual por cada heredero de la conmutación parcial. 
se requerirá ese mutuo acuerdo si son varios los tronqueros afectados por el usufructo sobre un único bien troncal ${ }^{62}$. En relación con este tema hay que tener en cuenta que el momento adecuado para ejercitar el derecho de conmutación es el de la partición de la herencia. Por esta razón, es difícil imaginar algún supuesto en el que el tronquero sea titular en exclusiva de un bien y pueda exigir su conmutación de forma independiente a los demás, con carácter previo a la partición. Lo habitual será que, hasta que la partición y adjudicación se lleve a cabo, los tronqueros formen parte de la comunidad hereditaria y, en consecuencia, sea necesario su acuerdo unánime para decidir la sustitución. Una vez producida la adjudicación, es posible acordar la conmutación, pero en este caso no nos hallaremos ante un derecho de los tronqueros amparado en el párrafo tercero del artículo 58 y exigible al viudo, sino a un acuerdo entre heredero y supérstite sometido a las reglas generales de la contratación.

Por último, conviene poner de relieve que el viudo tendrá sobre el capital que se le haya atribuido en sustitución del usufructo vidual sobre la mitad o los dos tercios de todos el patrimonio del causante, una total disponibilidad y, en consecuencia, podrá hacer con él lo que tenga por conveniente sin que, además, el hecho de que pueda incurrir en alguna de las causas de extinción del derecho a que se refiere el último párrafo del artículo 58 le afecte. Por tanto, ni las ulteriores nupcias, ni la posterior unión marital de hecho, ni el supuesto de tener un hijo no matrimonial ajeno a la relación que debe dar lugar al derecho determinarán la pérdida de la titularidad de ese capital $^{63}$.

También es de destacar que la posibilidad concedida al tronquero únicamente se prevé para el caso específicamente previsto en el artículo 58 -es decir, en el caso del usufructo atribuido por la Ley- pero no en aquellos otros supuestos en los que el derecho de uso y disfrute ha sido concedido por el causante, como es el supuesto del usufructo universal amparado en el artículo 61, o el que pueda corresponderle en caso de disolución del régimen foral de comunicación de bienes al haber sido designado comisario de la sucesión por el causante, mientras no haga uso del poder testatorio -siempre y cuando el premuerto no hubiera dispuesto lo contrario-, de conformidad con lo establecido en el artículo 105 de la Ley 3/1992. De alguna manera, lo que aquí se está premiando es la voluntad del causante: si éste ha dispuesto en

\footnotetext{
${ }^{62}$ Vid. Celaya Ibarra, A., «Comentarios al artículo 58 de la Ley del Derecho civil foral del País Vasco», en «Comentarios al Código civil y Compilaciones forales», dirigidos por M. Albaladejo y Silvia Díaz Alabart (dirs.), t. xxvi, Edersa, Madrid, 1997, p. 254.

${ }^{63}$ En mi opinión, si el hijo no matrimonial se tiene con otra persona durante la vigencia del matrimonio o de la relación de pareja, aun cuando se ponga de manifiesto este hecho con posterioridad al fallecimiento del cónyuge o compañero, sí que se producirá la pérdida puesto que, propiamente, la causa de extinción -que, en mi opinión debiera conceptuarse más como causa de exclusión del derecho- existiría con carácter previo a la muerte de aquél, es decir, antes de que se hubiera producido la conmutación.
} 
favor del viudo concediéndole un determinado derecho o atribuyéndole la condición de comisario - que legalmente lleva aparejada el usufructo sobre sus bienes- debe respetarse esa decisión y no atribuir a los herederos una opción que restringiría la propia voluntad del fallecido. Solamente en aquellos casos en los que el usufructo es el resultado de una atribución directa de la Ley -caso contemplado en el artículo 58- cabe otorgar la opción de sustitución a los herederos tronqueros porque es la propia Ley que ha concedido el derecho al viudo la que plantea la posibilidad de su conmutación.

\section{Conclusiones}

Como ya hemos avanzado en la introducción del presente artículo, éste no es más que una parte de una obra de mayor extensión en la que se completa el estudio del usufructo legal del viudo en Vizcaya que aquí se presenta, con el análisis de sus causas de extinción, añadiéndose, además, el examen de otros derechos usufructuarios previstos en la legislación civil del País Vasco, como son el usufructo universal derivado del poder testatorio, el usufructo poderoso del Fuero de Ayala y el legado de usufructo universal.

Pues bien, ahora vamos a intentar resumir en este apartado las principales conclusiones que a lo largo de este trabajo hemos alcanzado en relación con la naturaleza jurídica, los requisitos y el objeto del usufructo legal del viudo previsto para Vizcaya en la Ley 3/1992, de 1 de julio, de Derecho civil foral del País Vasco, dejando para la segunda parte de este estudio, que será publicada en una segunda entrega, el extracto de aquellas otras que alcancemos al analizar la extinción de ese mismo usufructo legal del viudo en Vizcaya, y las demás figuras antes mencionadas.

Sucintamente, y sin ánimo de ser exhaustivos, podemos destacar lo siguiente:

- Del análisis efectuado hemos deducido que en el modelo vizcaíno existe una estrecha relación entre los derechos hereditarios concedidos al viudo por la Ley y el régimen económico matrimonial legal de comunicación foral de bienes. La combinación de un régimen económico matrimonial legal de amplia comunidad, como es éste, y unos derechos sucesorios, en cierta medida reducidos, convierten el caso vizcaíno en un ejemplo -con las matizaciones que en su lugar se realizan- de la afirmación doctrinal de que los regímenes económicomatrimoniales de tipo ganancial suelen ir acompañados de limitados derechos sucesorios y, a la inversa, que los regímenes de separación suelen combinarse con amplios derechos mortis causa a favor de los viudos.

- En relación con la naturaleza jurídica, hemos puesto de relieve que nadie ha cuestionado la naturaleza sucesoria de este usufructo legal del 
viudo. De hecho, la finalidad familiar que en otros Derechos forales -como es el caso del aragonés- se atribuye al usufructo vidual, se ha visto en el caso vizcaíno en el específico régimen económico-matrimonial de comunicación: el hecho de que el viudo adquiera la mitad de los bienes de la comunidad y de que se consolide la comunicación con los hijos o descendientes que sean sucesores del premuerto hasta el momento de la división y adjudicación, es lo que le va a permitir dirigir adecuadamente la familia. Sobre todo si tenemos en cuenta que a él le corresponderá, en principio, la representación y administración de la herencia en tanto que ésta no sea aceptada y que, además, si es nombrado comisario, salvo disposición en contrario, tendrá el usufructo sobre toda ella. La determinación de la naturaleza jurídica sucesoria de este derecho es importante porque de ello se deriva que puedan aplicarse a esta institución determinados preceptos legales propios de las instituciones sucesorias tales como los relativos a las causas de indignidad, los cuales pueden resultar determinantes para establecer la incapacidad del viudo para la adquisición del usufructo o, en su caso, para producir su extinción.

- Por lo que se refiere a los requisitos necesarios para acceder al usufructo vidual legal, el primero que hemos mencionado es el de la subsistencia del matrimonio o de la pareja de hecho. En efecto, de lo dispuesto en los artículos 58 y 59 de la Ley 3/1992, en combinación con lo previsto con el artículo 18 de la Ley $2 / 2003$, se deduce que para poder acceder al derecho el supérstite debía estar unido al causante, en el momento del fallecimiento de éste, por un vínculo matrimonial que no hubiera sido disuelto, o por una relación de pareja de hecho que no se hubiera extinguido por causa distinta de la muerte o, en el segundo caso, por matrimonio entre los dos miembros de la pareja. Defendíamos también la posibilidad de que los herederos pudieran mantener la acción de nulidad o divorcio planteada por el después fallecido a los solos efectos de determinar la inexistencia del derecho del viudo al usufructo, con fundamento en el artículo 74 del Código civil, si bien con las excepciones del artículo 75, y teniendo en cuenta lo dispuesto en el 79 del mismo texto.

- Otro de los requisitos exigidos para que el derecho nazca es que el cónyuge supérstite no se encontrara separado por causa a él imputable. En este punto observamos una importante diferencia con el tratamiento ofrecido por el Código civil ya que la Ley 3/1992 va a permitir acceder al derecho a los cónyuges separados siempre y cuando no exista culpabilidad en el posible titular del usufructo, cosa que no sucede en territorio común, donde, de conformidad con el artículo 834 del Cc, ninguno de los consortes separados, ya sea judicialmente, ya sea de hecho, podrá ser titular del usufructo vidual. Por otro lado, según el principio de libertad civil recogido en el artículo 4 de la Ley vasca, 
abogamos en este trabajo por la posibilidad de considerar aplicable el perdón o la reconciliación a los efectos de impedir que la separación entre en juego como causa impeditiva del usufructo. En otro orden de cosas no hemos encontrado argumentos definitivos que nos hagan exigir que la separación sea judicial para que impida el nacimiento del derecho. El tenor del artículo 59 no distingue, a este respecto, entre separación de hecho y de derecho, y, en consecuencia, una interpretación literal debe llevarnos a entender que también la separación de hecho, si es imputable al posible titular del usufructo, debe provocar que este derecho no llegue a nacer.

- El tercero de los requisitos señalados en el trabajo es el de no tener un hijo fuera del matrimonio o de la relación de pareja, durante su vigencia. La Ley propiamente habla de este hecho como una causa de extinción del usufructo; sin embargo, entendemos que tal consideración es errónea. En realidad, nos hallamos ante un requisito para poder acceder al derecho y no ante una causa de extinción.

- Por último, según la consideración del usufructo legal del viudo como un derecho sucesorio, hemos defendido como requisito para acceder a éste el no incurrir en las causas de indignidad para suceder que se recogen en el artículo 756 del Código civil. Respecto a ellas hemos concluido lo siguiente:

a) No resulta aplicable a este supuesto, a nuestro entender, la incapacidad para suceder consistente en el abandono, prostitución o corrupción de los hijos, pues es ésta una causa que piensa en la incapacidad de suceder del padre en la herencia del hijo al que abandona, prostituye o corrompe.

b) En relación con la condena en juicio por haber atentado contra la vida del cónyuge, compañero en la relación estable, descendientes y ascendientes, la entendemos absolutamente determinante de que el derecho del viudo no nazca, considerando que el único supuesto que no funciona propiamente como un requisito de acceso, sino como determinante de la extinción del derecho ya nacido, es el caso de los atentados contra la vida de los ascendientes o descendientes del cónyuge o pareja llevados a cabo tras el fallecimiento de éste. En tales supuestos el viudo habría ya entrado en posesión de los bienes usufructuados puesto que era capaz en el momento de la apertura de la sucesión.

c) Con relación a la acusación del supérstite contra el premuerto de un delito al que la Ley señale pena grave de prisión de, al menos, tres años, que hubiese sido declarada calumniosa por sentencia firme, debemos entender que, si la sentencia adquiere firmeza antes del fallecimiento del consorte o compañero, resulta evidente la carencia del supérstite de los requisitos necesarios para acceder al usufructo. Y si la firmeza se produce con posterioridad, deberemos esperar a 
ese momento para calificar la capacidad, quedando el usufructo en suspenso hasta entonces.

d) Respecto a la ausencia de denuncia de la muerte violenta del cónyuge o pareja, para que el comportamiento indigno pueda tener alguna trascendencia sobre la capacidad sucesoria, deberemos esperar al transcurso de un mes desde el fallecimiento del causante, de tal forma, que si para entonces no se ha producido la denuncia del supérstite pese al conocimiento de éste de la causa violenta de la muerte existirá incapacidad para suceder, quedando en el interín el derecho en suspenso.

e) En relación con la coacción al cónyuge o compañero para otorgar testamento o modificarlo o para impedirle testar, forzarle a revocarlo o a su suplantación, ocultación o alteración, hemos entendido que, aun cuando con dichas actuaciones no se persiga la obtención de un beneficio particular, quien así obre debe verse excluido del usufructo en la medida que su actitud revela la falta de confianza absoluta que merece y que es parte del fundamento de este derecho legitimario.

f) Por último, en lo que se refiere a la no prestación de atenciones debidas al cónyuge o compañero discapacitado, hemos entendido que existe indignidad para adquirir el derecho usufructuario por el simple hecho de darse de facto un incumplimiento de las atenciones reguladas en los artículos 142 y ss. del Código civil, aun en el supuesto de que no exista sentencia de condena contra el infractor. Bastará con que cualquier interesado ejercite las acciones necesarias para que sea declarada la indignidad con efectos desde la fecha de fallecimiento del causante.

- Para finalizar, con relación al objeto del usufructo legal del viudo, hemos puesto de manifiesto como en el Derecho civil vizcaíno, en comparación con lo que sucede en el Código civil, se prima al viudo en el caso de que existan descendientes ya que, en tal supuesto, se le atribuye el usufructo sobre la mitad de todos los bienes de la herencia, frente al tercio de libre disposición afectado que recoge el Código civil. En concreto, en la actualidad, si el supérstite concurre con descendientes o ascendientes, su usufructo alcanza a la mitad de todos los bienes y, si no concurre con ellos, abarcará los dos tercios. Este derecho, además, es independiente del régimen económico que rija el matrimonio, lo que diferencia la situación actual de la existente con la Compilación, pues, entonces, si se había pactado un régimen de separación de bienes, el viudo no gozaba de protección ni a través del régimen económico matrimonial ni a través de un derecho legal de usufructo. Como novedad, además, la Ley del Derecho civil del País Vasco extiende el derecho a un porcentaje sobre todos los bienes del causante y no deja fuera del cálculo los bienes troncales 
tal y como ocurría con la Compilación. Es cierto que la Ley ha querido preservar el tronco, pero lo ha hecho sólo en la medida que esa protección no afecte al derecho del viudo; es decir, ahora, si existen bienes no troncales suficientes, el usufructo recaerá sobre ellos, pero si éstos no son suficientes, podrán afectarse los pertenecientes al tronco.

\section{Bibliografía}

Albadalejo García, M., Curso de Derecho Civil V. Derecho de Sucesiones, Ed. Bosch, Barcelona, pp. 82-88.

— «Comentarios a los artículos 756, 757 y 758 del Código Civil» en AlbADAlejo, M. (dir.), Comentarios al Código Civil y Compilaciones Forales, tomo $\mathrm{x}$, vol. $1 .^{\circ}$, pp. 196254.

Angoitia Gorostiaga, V. y Galicia AizPurúa, G., «Las legítimas y la libertad de disposición en la Ley de Derecho civil del País Vasco» en VV. AA. Derechos civiles de España, vol. I, Ed. Aranzadi, 2000, pp. 373-410.

Arregui Gil, J., «Comentarios a las Leyes 253, 261 y 262 de la Compilación navarra» en Albadalejo, M. y Díaz Alabart, S. (dirs.), Comentarios al Código Civil y Compilaciones Forales, tomo XXXVII, vol. 2. ${ }^{\circ}$, Edersa, Madrid, 2001, pp. 30-54 y 132-150.

Celaya IbarRa, A., «Comentarios a los artículos 32 al 48, 53 al 64 y 104 al 107 de la Ley de Derecho civil foral del País Vasco» en Albadalejo, M. y Díaz Alabart, S. (dirs.), Comentarios al Código Civil y Compilaciones Forales, tomo XXVI, Edersa, Madrid, 1997, pp. 161-202, 226-269 y 471-484.

Diez Picazo, L. y Gullón Ballesteros, A., «La legítima y la mejora», Sistema de Derecho Civil. Volumen IV (Derecho de Familia. Derecho de Sucesiones), Ed. Tecnos, Madrid, 8. ${ }^{a}$ edición, 2003, pp. 417-447.

— «La delación de la herencia», op. cit.,pp. 303-319.

GONZÁlEZ CARAZO, J. L., «El poder testatorio y el testamento por comisario en el Derecho Foral de Vizcaya» en VV. AA., Derechos civiles de Espa$\tilde{n} a$, vol. I, Ed. Aranzadi, 2000, pp. 411-455.

Gullón Ballesteros, A., «El párrafo 3. ${ }^{\circ}$ del artículo 820 del Código Civil», Anuario de Derecho Civil, 1961, pp. 875-895.

- «La conmutación del usufructo legal del cónyuge viudo», Anuario de Derecho Civil, 1964, pp. 583-619.

LACRUZ BERDEJO, J. L., «Cuestiones fundamentales de viudedad foral navarra» en Revista Crítica de Derecho Inmobiliario, año XL, septiembreoctubre, 1964, n. $^{\circ} 436-437$, pp. 553-584.

— «La legítima del cónyuge viudo», Elementos de Derecho Civil V. Derecho de Sucesiones, Ed. Bosch, Barcelona, 1988, pp. 500-506.

— «Indignidad e incapacidad», op. cit., pp. 78-85. 
Latorre MARTínez de BAROJA, E., «Comentarios a los artículos 72 a 86» en Albadalejo, M. (dir.), Comentarios al Código Civil y Compilaciones Forales, tomo XXXIII, vol. 2. ${ }^{\circ}$, Edersa, Madrid, 1990, pp. 282-404.

Piedrabuena Molina, P., «La comunicación foral de bienes en Vizcaya» en VV. AA., Derechos Civiles de España, vol. I, Ed. Aranzadi, 2000, pp. 341-361.

PUIG BRUtAU, J., «Incapacidad, prohibición e indignidad para suceder» en

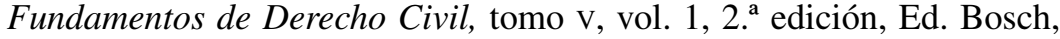
Barcelona, 1975, pp. 126-150.

Sancho Rebullida, F. y de Pablo Contreras, P., «Comentarios a los artículos 72 a 88 (La viudedad)» en Delgado Echeverría, J. (dir.), Comentarios a la Compilación del Derecho Civil de Aragón, DGA, vol. II, Zaragoza, 1993.

VALLET DE Goytisolo, J., «Comentarios a los artículos 807 y 834 a 857 del Código Civil» en Albadalejo, M. (dir.), Comentarios al Código Civil y Compilaciones Forales, tomo XI, 2. ${ }^{a}$ edición, Edersa, Madrid, 1982, pp. 30-48 y 446-516.

ZabAlo Escudero, M. E., La situación jurídica del cónyuge viudo en el Derecho internacional privado e interregional, Ed. Aranzadi, Pamplona, 1993.

ZAPATERO GONZÁLEZ, R., «De la viudedad foral» en Actas de las Jornadas de Derecho Civil Aragonés (Jaca 1985), Cortes de Aragón, pp. 239-ss. 